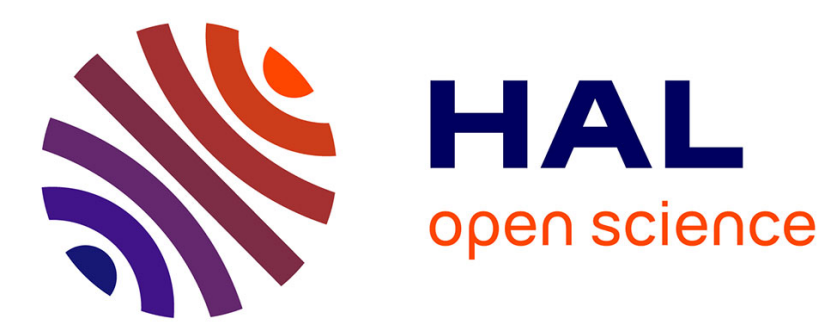

\title{
Ferrocifen type anti cancer drugs
}

Gérard Jaouen, Anne Vessières, Siden Top

\section{To cite this version:}

Gérard Jaouen, Anne Vessières, Siden Top. Ferrocifen type anti cancer drugs. Chemical Society Reviews, 2015, 44 (24), pp.8802-8817. 10.1039/C5CS00486A . hal-01221048

\section{HAL Id: hal-01221048 \\ https: / hal.sorbonne-universite.fr/hal-01221048}

Submitted on 27 Oct 2015

HAL is a multi-disciplinary open access archive for the deposit and dissemination of scientific research documents, whether they are published or not. The documents may come from teaching and research institutions in France or abroad, or from public or private research centers.
L'archive ouverte pluridisciplinaire HAL, est destinée au dépôt et à la diffusion de documents scientifiques de niveau recherche, publiés ou non, émanant des établissements d'enseignement et de recherche français ou étrangers, des laboratoires publics ou privés. 


\section{Ferrocifen Type Anti Cancer Drugs}

Gérard Jaouen, $^{\mathrm{a}, \mathrm{b}, \mathrm{c} *}$ Anne Vessières, ${ }^{\mathrm{a}, \mathrm{b}}$ Siden Top ${ }^{\mathrm{a}, \mathrm{b}}$

a Sorbonne Universités, UPMC Univ Paris 06, IPCM, F-75005 Paris, France

${ }^{\mathrm{b}}$ CNRS, UMR 8232, IPCM, F-75005 Paris, France

${ }^{\text {c }}$ PSL Research University, Chimie ParisTech, 11 rue Pierre et Marie Curie, F-75005 Paris, France

\section{Corresponding author :}

Prof G. Jaouen, Chimie ParisTech, 11 rue Pierre et Marie Curie, F-75005 Paris, France.

Tel : $33(0) 143269555$

Email : gerard.jaouen@chimie-paristech.fr

to the memory of Professor Lord (Jack) Lewis, an inspiring mentor 


\section{Biography}

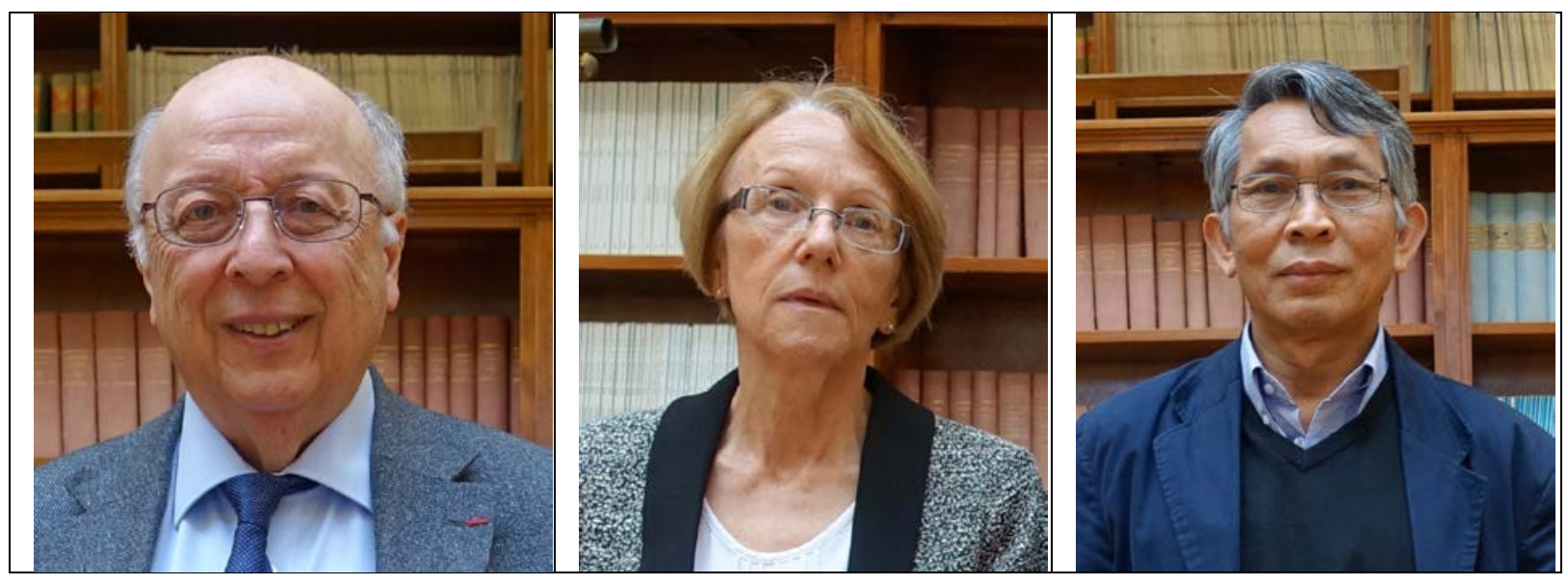

Professor Gérard Jaouen received his doctorate from the University of Rennes (France) in 1973, and spent the year 1973-1974 at Cambridge working with Professor Lord (Jack) Lewis. He became Professor at the University of Paris 6 (ENSCP) in 1982, where he set up a CNRS Associated Laboratory and decided to focus on bioorganometallic chemistry. This initially embryonic field has now flourished. He is the editor of 3 books, the author of 425 papers, including 18 chapters and reviews, and has filed 16 patents. His achievements in the field have been recognized by several international awards. He was awarded Knight of the "Légion d'Honneur" (2006), and was elected as a fellow of the European Academy of Sciences and a member of the Academia Europaea (2012)

Anne Vessières, a Director of Research in the CNRS, earned doctorates in both organometallic chemistry (1974) and biochemistry (1980) from the University of Rennes (France). She spent several periods as a visiting scientist at McGill University, Montreal, with Professor Ian S. Butler, and at the Jules Bordet Hospital, Brussels, with Professor Guy Leclercq. In 1982 she helped to set up the Organometallic Chemistry Laboratory at the ENSCP. Her two main fields of interest are Medicinal Chemistry and the use of metal carbonyl complexes for mid-infrared detection. In 2012 she was awarded the Elsevier Award for Outstanding Achievements in Bioorganometallic Chemistry

Siden Top, born in Cambodia, is a Director of Research in the CNRS. In 1972 he was awarded a fellowship to study in France where he obtained a "Docteur Ingénieur” degree in Dijon (1976) and a $\mathrm{PhD}$ in 1979 in Rennes, working with Professors R. Dabard and G. Jaouen. In 1982, he moved to the ENSCP and has worked mainly on bioorganometallics. He spent the year 1987 with Professor H. D. Kaesz at UCLA, and several short periods with Professor M. J. McGlinchey at McMaster University. His research focuses on the development of organometallic compounds as anticancer agents and radiopharmaceuticals. 
Abstract: Despite current developments in therapeutics focusing on biotechnologicallyoriented species, the unflagging utility of small molecules or peptides in medicine is still producing strong results. In 2014 for example, of the 41 new medicines authorized for sale, 33 belonged to the category of small molecules, while in 2013 they represented 24 of 27, according to the FDA. This can be explained as the result of recent forays into new or longneglected areas of chemistry. Medicinal organometallic chemistry can provide us with an antimalarial against resistant parasitic strains, as attested by the phase II clinical development of ferroquine, with a new framework for conceptual advances based on three-dimensional space-filling, and with redox or indeed catalytic intracellular properties. In this context, bioferrocene species with antiproliferative potential have for several years been the subject of sustained effort, based on some initial successes and on the nature of ferrocene as a stable aromatic, with low toxicity, low cost, and possessing reversible redox properties. We show here the different antitumoral approaches offered by ferrocifen derivatives, originally simple derivatives of tamoxifen, which over the course of their development have proved to possess remarkable structural and mechanistic diversity. These entities act via various targets, some of which have been identified, that are triggered according to the concentration of the products. They also act according to the nature of the cancer cells and their functionality, by mechanistic pathways that can operate either synergistically or not, in successive, concomitant or sequential ways, depending for example on newly identified signaling pathways inducing senescence or apoptosis. Here we present a first attempt to rationalize the behavior of these entities with various anticancer targets.

\section{Introduction, Contextualizing the Problem}

We are now witnessing an explosion of cases of cancer, a disease whose multiform nature makes it very difficult to treat. We have reached the stage where we may be said to have entered "the Age of Cancer"1 with 6.5 million cancer deaths in 2003, reaching 12 million in 2013, and predictions for 2030 of 22 million deaths, 35 million by 2050. It is vital to give the lie to these dark predictions. The numbers reflect an increase that is statistically greater than the increase in population of the planet.

In parallel with this explosion of the disease, major innovations in the therapeutic approach to cancers, complementing established methods such as surgery and ionizing radiation, have appeared in the last decade. Progress has been made for example in improved targeting of cancerous sites, whether by the use of biodegradable nanoparticles, dendrimers, 
monoclonal antibodies, peptides or saccharides bound to appropriate ligands or indeed the use of microfluidics. ${ }^{2,3}$ All this contributes to the progress of chemotherapy and hormone therapy. But the improvements are also driven by a flood of biological information supporting the understanding of cancers and permitting greater personalization of treatment. Chemistry still often plays a central role, however, in bringing these new approaches to fruition.

It must nevertheless be borne in mind that the cost of these new highly targeted treatments is a pressing problem, placing a heavy burden on the health budgets of the majority of developed and developing countries. Herceptin, Mabthera, Avastin, flagship products of Roche, earned 21 billion dollars in 2013. ${ }^{1}$ Within the current progression, Kadcyla looks poised to enter the same territory. These drugs exemplify the biopharmaceutical approach (selective monoclonal antibodies for well-targeted cancers, but at exorbitant public cost).

If we hope to find new active principles while holding down costs, we need to look in the direction of innovative chemotherapies, ideally outside the well-worn paths of traditional chemistry. Interestingly, these days, the traditional disciplines of chemistry appear to be undergoing a profound and rapid evolution, for example in chemical biology, in their drive to explore new directions beyond the well traveled pathways, and to build structures of increasing complexity and diversity. Molecular chemistry is no exception to this fundamental trend.

In particular, we are currently perceiving a scientific interest in a diversity of structures produced by inorganic syntheses. ${ }^{4}$ This approach has already broken through into the domain of healthcare, whether in therapy, thanks for instance to the importance of Pt coordination metallodrugs or in diagnostic imaging, with MRI contrast agents based on Gd, or indeed in radiopharmaceuticals designed around the radionucleide ${ }^{99 \mathrm{~m}} \mathrm{Tc}$, to give only a few examples.

In this context the value of platinum coordination complexes in oncology is well known with three of these complexes (vide infra) being used, alone or in combination, in $70 \%$ of cancer treatments. ${ }^{5}$ This is despite the well-documented disadvantages of these DNA alkylating agents; their use is in fact sometimes only the result of a lack of alternatives. The coordination complexes of Pt induce cell death primarily by apoptosis thus they are ineffective in the treatment of tumor cells resistant to this pathway. This is often the case with cancers that are difficult to treat and that have poor outcomes. Considering these gaps in the therapeutic arsenal a coordination chemistry of Ru has been explored and some promising molecules such as NAMI-A or KP1019 have been obtained (Chart 1). ${ }^{6}$ 


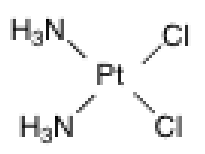

Cisplatin

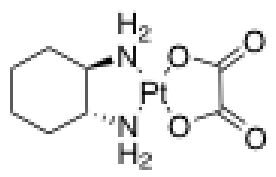

Oxaliplatin

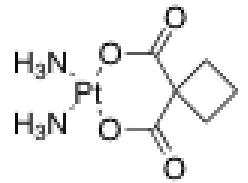

Carboplatin
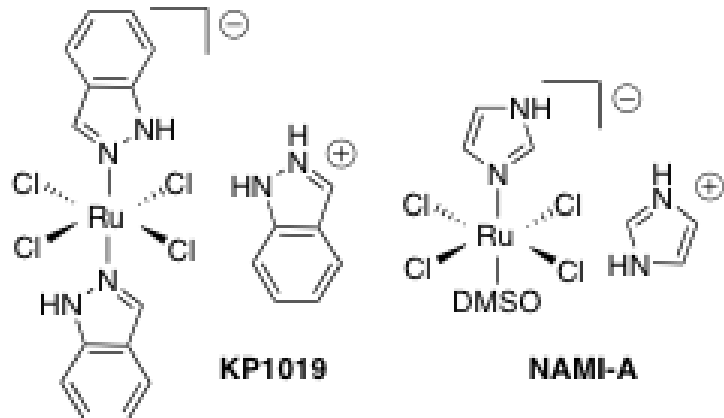

NAMI-A

Chart 1 : Selected examples of inorganic anticancer drugs

However it is now crucial to find a new and effective angle of attack, probably by taking advantage of novel mechanisms of action. It is in this context that the development of a new medicinal organometallic chemistry may provide a key, thanks to the novel behavior of these molecules. ${ }^{4,6}$ The primary difference between a coordination complex of the cisplatin type and an organometallic compound is in their chemical binding mechanism, resulting in different chemistries, depending on the category to which the complex belongs. The metallodrugs of Pt require aquation to activate them and often have DNA as their primary target which is probably not exclusive. ${ }^{5}$ Whereas the organometallics, which tend to be more lipophilic and have a carbon-metal (C-M) covalent bond, function differently on protein targets. This complementarity may prove to be a valuable asset. Of added interest is that the identification of multiple targets within cancerous cells may support the synthesis of multiplerecognition drugs, with the objective of overcoming resistance to apoptosis by inducing cell growth arrest via another pathway, senescence for example. ${ }^{7}$

The arrival of organometallic frameworks constructed by design, with a precise biological endpoint in mind, was somewhat delayed, owing to an emphasis on catalysis which for some years had the effect of relegating other aspects of the field to obscurity. This situation changed with the arrival of bioorganometallics. ${ }^{8,9}$ It is now clear that an innovative organometallic medicinal chemistry is supported by the distinctive properties of these complexes. Among the most studied series of organometallic anticancer drug candidates are the lead molecules shown below (Chart 2). 4, 6, 8, 10 


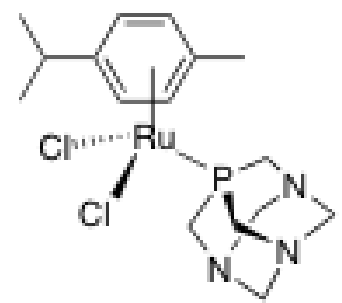

RAPTA-type

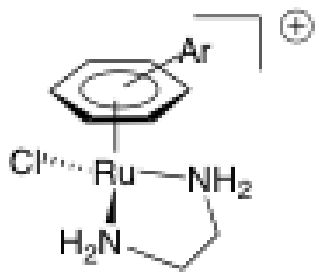

$\left[\mathrm{Ru}\left(\eta^{6} \text {-arene) }\right)(e n) \mathrm{CI}\right]^{+}$

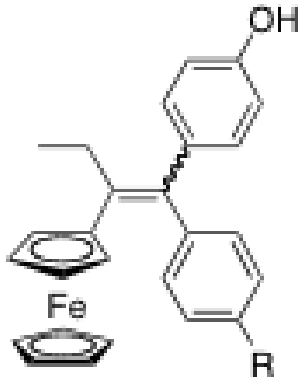

Ferrocifen type $\left(\mathrm{R}=\mathrm{O}\left(\mathrm{CH}_{2}\right)_{n} \mathrm{~N}\left(\mathrm{CH}_{3}\right)_{2} ; \mathrm{OH}\right)$

Chart 2 : Selected examples of organometallic anticancer drug candidates

These molecules and related species have been conceived for a specific purpose. The social challenge represented by those cancers that still have alarmingly poor outcomes (e.g. glioblastoma, melanoma, ovarian, pancreatic and triple negative breast cancers) ${ }^{7}$ can only be met by a capacity for medical innovation, drawing from a judicious alliance of ground breaking chemistry, novel biology and the latest tools of medical intervention. These cancers share the characteristic of intrinsic resistance to pro-apoptotic stimuli, which limits the effectiveness of the available chemotherapies, hence the need to discover new therapeutic approaches able to induce cell death or senescence by other means. In this endeavor new medicinal chemistry based on the unique behavior of organometallic complexes of transition metals may provide a turning point.

\section{Selection of antiproliferative bioferrocene compounds with varied structures}

In the search for medically-interesting organometallic molecules with novel mechanistic properties, various metals, many of them rare, have been considered for the central position in the complex. These include, amongst others, $\mathrm{Au}, \mathrm{Ru}, \mathrm{Os}, \mathrm{Re}, \mathrm{Tc}, \mathrm{Rh}, \mathrm{Ir}, \mathrm{Ti}$. 4, 6, 7, 11-19 Within this framework a number of complexes have been the subject of in-depth mechanistic studies. ${ }^{4,6,18}$ One series of organometallic complexes with particularly intense activity is that of the $\mathrm{N}$-heterocyclic carbene complexes, particularly those of gold. ${ }^{13}$ This research stems from the discovery of these heterocyclic ligands by Lappert starting in 1973. One could probably attribute the first biological application of these complexes, using this type of carbene ligand with $\mathrm{Ru}$ and $\mathrm{Rh}$ as antibacterials, to former collaborators of Lappert, the Cetinkayas, in 1996 . $^{20}$ This pioneering work was not followed up at the time as it was eclipsed by the second generation of Grubbs metathesis catalysts, which appeared in 1999 . Here we can see a possible link between bioorganometallics and homogeneous catalysis in terms of the nature of the complexes that can be used. This has just been brilliantly confirmed 
by Sadler et al. who have shown that a Noyori-type hydrogenation catalysis can be carried out in cancer cells to provide a new mechanism of anticancer activity. ${ }^{21}$

Of the transition metals that are more abundant than those cited in the previous paragraph, iron, especially in the form of ferrocene, a compact metallocene possessing stability in non-oxidating media, low toxicity, and reversible redox behaviour, has recently played an important role in bioorganometallics, as an antiparasitic or an antibacterial, ${ }^{22-24}$ and indeed as an antitumoral agent. The latter aspect is amply illustrated in recent publications. ${ }^{25-}$ 27

Some examples of the vast and regularly increasing number of bioferrocene compounds with antitumoral potential are shown in Chart 3 below. They illustrate the richness of the activity in this field, the variety of the structures brought into play and the diversity of possible angles of attack. This bodes well for the variety of mechanisms involved even if only a minority of them has so far been reliably elucidated. 
Selective Estrogen Receptor Modulators (SERMs ; 1-4)

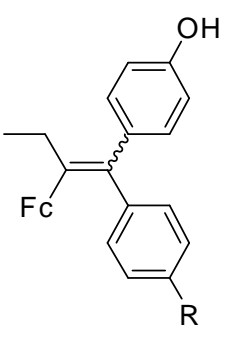

1a: $\mathrm{R}=\mathrm{O}\left(\mathrm{CH}_{2}\right)_{3} \mathrm{~N}\left(\mathrm{CH}_{3}\right)_{2}$

1b: $\mathrm{R}=\mathrm{OH}$

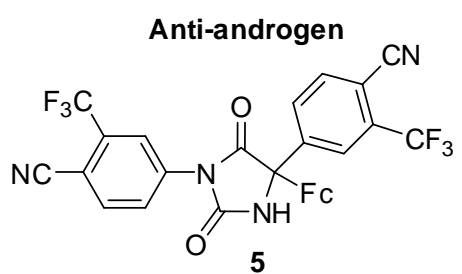

5

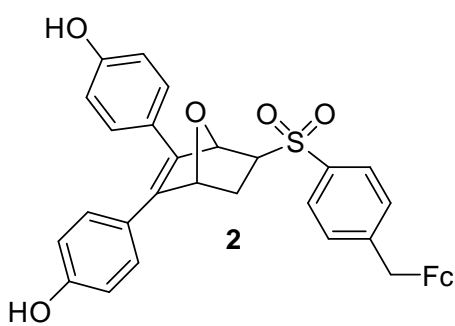

$\mathrm{HO}$

$$
\text { Natural products }(6-10)
$$<smiles>O=c1cc(F)oc2c(Br)cc(Br)cc12</smiles>

6<smiles>CCc1ccccc1</smiles><smiles>CC1=C2C(=CC1(C)C)C(=O)C(O)(O)C1(CC1)[C@@H]2OC(=O)c1ccccc1C(=O)c1ccccc1</smiles>

Kinase inhibitor<smiles>O=C(F)Nc1ccc2c(c1)/C(=C/c1ccc[nH]1)C(=O)C2</smiles>

11

Mitochondria targeted compound<smiles>F/C=C/c1cc[n+](CCCC[Pb])cc1</smiles>

16

Peptide derivative

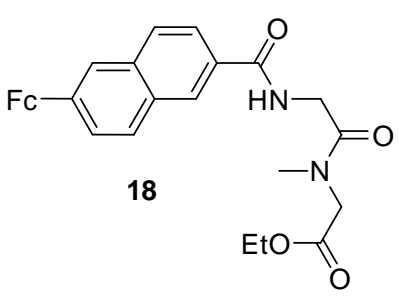

\section{DNA Intercalator}<smiles>COc1ccc2nc3cc(Cl)ccc3c(NCCF)c2c1</smiles>

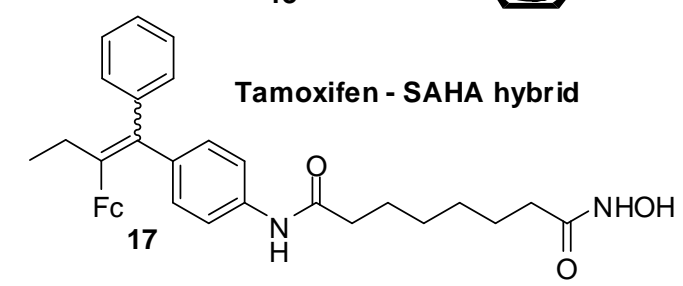<smiles>COC1O[C@H](Cn2cc(CNC(=O)C(F)(F)F)nn2)[C@H]2OC(C)(C)O[C@H]12</smiles>

19
Fc-amino derivative<smiles>CC1(C)OB(c2ccc(COC(=O)N(CF)Cc3ccccc3)cc2)OC1(C)C</smiles>

Chart 3 : Selected bioferrocene compounds 
The ferrocifens 1a-b (Fc-OH-Tam and Fc-diOH) derived from hydroxytamoxifen (OH-Tam) are among the earliest organometallic SERMs (selective estrogen receptor modulators) known since they were described for the first time in $1996 .{ }^{28-30}$ They possess the unusual feature of being antiproliferative on both hormone-dependent (MCF-7) and hormoneindependent (MDA-MB-231) breast cancer cells ( $\mathrm{IC}_{50}$ of Fc-OH-Tam : 0.8 and $0.5 \mu \mathrm{M}$ respectively) breast cancer cells, with good efficacies. Such a dual effect is remarkable since the corresponding purely organic form shows antiestrogenic activity only on hormonedependent MCF-7 breast cancer cells. This reveals the significance of the ferrocenyl (Fc) unit and has led to many further studies (vide infra).

In particular, other ferrocene SERMs have since been brought to light. An example is $\mathbf{2}$ based on a three-dimensional oxabicyclo[2.2.1] heptene scaffold. ${ }^{31}$ These entities, like 1, recognize both ER $\alpha$ and its isoform ER $\beta$. The species in this series are cytotoxic at micromolar concentrations ( $\mathrm{IC}_{50} \approx 7.5 \mu \mathrm{M}$ ) on both ER+ and ER- breast cancer cells. Molecular modeling studies suggest that these scaffolds bind to the ER receptor in a particular way. Studies of these new structures are encouraging.

Following a parallel approach to that used with the ferrocifens, another SERM, derived from raloxifen, $\mathbf{3}$, was prepared. ${ }^{32}$ This compound reveals cytotoxic activity on a number of cancer cell lines (breast, ovary, cervix, lung, colon) with $\mathrm{IC}_{50}$ values in the low micromolar range. This compound activates a caspase-3 in ovarian cells.

Another series similar to the type $\mathbf{1}$, that of the ansa ferrocenophanes such as $\mathbf{4}$ (ansa$F C$-diOH) has been reported. ${ }^{33}$ It is significantly more active than the acyclic series $\mathbf{1}$ with $\mathrm{IC}_{50}$ values on MDA-MB-231 cells in the order of $0.09 \mu \mathrm{M}$.

Unlike the compounds mentioned above $(\mathbf{1}$ - 4) which are SERMs that recognize and modulate estrogen receptors but which additionally show another type of cytotoxic activity against cancer cells, the ferrocenyl derivative of the antiandrogen nilutamide $\mathbf{5}$ does not show significant recognition of the androgen receptor and thus is not a SARM (Selective Androgen Receptor Modulator). ${ }^{34}$ However it shows significant anticancer activity against PC-3 hormone-independent prostate cancer cells $\left(\mathrm{IC}_{50}=4 \mu \mathrm{M}\right)$.

A number of natural compounds modified by a ferrocenyl unit are grouped together (6 - 10). They illustrate what can be expected from this type of modification. Several ferrocenyl taxoids such as $\mathbf{6}$ were prepared by acylation of paclitaxel and docetaxel with ferrocenyl carboxylic acids. The compounds obtained, such as $\mathbf{6}$, showed good activity against cell lines of multiresistant adenocarcinomas of the colon. The mechanisms of action of these species are 
currently under study. ${ }^{35}$

Several studies on ferrocenyl flavonoids have recently been carried out. A representative example is the dibrominated ferrocenyl flavone 7 . This type of flavone shows fairly low cytotoxicity on B16 murine melanoma cells but acts as an excellent antivascular agent. ${ }^{36}$ This antiangiogenic effect is interesting and merits further study. Related series such as ferrocenyl pterocarpene 8 and coumestan give IC $_{50}$ values between 20 and $45 \mu \mathrm{M}$ against various cancer cell lines while some members of the group are genotoxic. ${ }^{37}$

Curcumin is employed in the Asian diet for its medicinal properties. An example of its modification by ferrocen can be seen with $9 .{ }^{38}$ The spacer chain between the curcumin skeleton and the ferrocenyl group influences the biological results both in terms of the $\mathrm{IC}_{50}$ values on $\mathrm{B} 16$ murine cells $\left(\mathrm{IC}_{50}=2.2-7.1 \mu \mathrm{M}\right)$ and in the inhibition of tubulin polymerization and rounding up of endothelial cells. This reflects the role of the organometallic on the modification of the biological activities of the curcuminoids.

The extreme toxicity of illudin, produced by mushrooms, does not permit chemical application in its natural state. A modification using ferrocene reduces its toxicity on fibroblasts and increases its selectivity on cancer cells with species such as $\mathbf{1 0}{ }^{39}$ Heterocyclic skeletons bearing a ferrocenyl substituent also present some interesting behaviors. For example with the bioorganometallic oxindole, 11, kinase inhibition is obtained at submicromolar concentrations. ${ }^{40}$

There are also ferrocenyl-intercalator conjugates targeting DNA, such as acridine, with elevated cytotoxicity. This is the case for example with compound 12 which has $\mathrm{IC}_{50}$ values in the order of $1 \mu \mathrm{M}$ on several cancer cell lines (KB, Hep, Hela, Colo-206). ${ }^{41}$

Ferrocenyl alkyl nucleobases, as for example $\mathbf{1 3}$ with thymine, were easily synthesized. ${ }^{42}$ The antitumoral activity of $\mathbf{1 3}$ with models of solid tumors, for example with Ca755 (murine mammary carcinoma) and LLC (lung mouse carcinoma) were studied in vivo. A therapeutic synergism exists between $\mathbf{1 3}$ and the anticancer drug cyclophosphamide, shown by a $70 \%$ inhibition of tumor growth. Other analogs of ferrocenyl nucleosides showing apoptosis-inducing activity were obtained via a very elegant enantioselective synthesis by Schmalz et al. ${ }^{43}$ A promising example of a diastereomer treating ex vivo primary lymphoblasts isolated from children is $\mathbf{1 4}$ which appears to make it possible to overcome resistance. Other interesting organometallic nucleoside analogs with ferrocenyl linkers have recently been published. $^{44}$

Azolactone ferrocene $\mathbf{1 5}$ is a potential inhibitor of the catalytic activity of the 
topoisomerase $\mathrm{II} \beta\left(\mathrm{IC}_{50}=100 \mu \mathrm{M}\right)$ by cleavable complex formation, while a related thiomorpholide amido methyl ferrocene competes with ATP binding $\left(\mathrm{IC}_{50}=50 \mu \mathrm{M}\right){ }^{45}$

Balaji et al. recently published a novel study on mitochondrial targeting of photocytotoxic compounds of ferrocenyl conjugates with salts of $\mathrm{N}$-alkylpyridinium such as the one shown in $\mathbf{1 6} .^{46}$ This type of conjugate, 16, reveals photocytotoxicity in HeLa cancer cells $\left(\mathrm{IC}_{50}=1.3 \mu \mathrm{M}\right)$ that is markedly higher than that found in normal $3 \mathrm{~T}_{3}$ cells $\left(\mathrm{IC}_{50}=\right.$ $27.5 \mu \mathrm{M})$ with visible light $(400-700 \mathrm{~nm})$. Apoptosis is induced via an intrinsic mitochondrial pathway giving rise to reactive oxygen species (ROS). DNA photocleavage activity occurs by formation of hydroxyl radicals $\left(\mathrm{OH}^{\circ}\right)$.

Another recently published conjugate, 17, ferrocenyl tamoxifen-SAHA may open a new therapeutic route through the intervention of other targets. This hybrid $\mathbf{1 7}$ shows good cytotoxicity on triple negative MDA-MB-231 breast cancer cells $\left(\mathrm{IC}_{50}=0.7 \mu \mathrm{M}\right.$ ), while FcTam and SAHA alone give $\mathrm{IC}_{50}$ values of $2.6 \mu \mathrm{M}$ and 3. $\mu \mathrm{M}$ respectively, and $\mathrm{IC}_{50}=8.6$ $\mu \mathrm{M}$ for the organic hybrid. The estrogen receptor ER $\alpha$ and histone deacetylase (HDAC) are not the principal targets of this hybrid. ${ }^{47}$

The literature also reveals several ferrocenyl conjugates of peptides, as for example the derivative of naphthyl $\mathbf{1 8}{ }^{48}$ In this series there is a wide variety of peptide entities. For example 18 gives an $\mathrm{IC}_{50}$ value of $0.14 \mu \mathrm{M}$ on the $\mathrm{H}_{1} 299 \mathrm{NSCLC}$ cell line, and $\mathrm{IC}_{50}=1.06$ $\mu \mathrm{M}$ for the sk-MCI-28 malignant melanoma cell line. This type of compound induces apoptosis through oxidative damage via a redox mechanism by ROS.

Sugars are also playing their part, as attested by $\mathbf{1 9}$, carbohydrate ferrocene conjugates with amide-triazole linkers. ${ }^{49}$ Compounds derived from xylose and ribose show a cytotoxic effect on hormone-dependent (MCF-7, $\left.\mathrm{IC}_{50}=3.18 \mu \mathrm{M}\right)$ and hormone-independent (MDAMB-231, $\left.\mathrm{IC}_{50}=7.31 \mu \mathrm{M}\right)$ cancer cells lines, while conjugates derived from glucose and galactose do not.

The synthesis of N-benzyl-substituted aminoferrocene-based prodrugs has recently been improved, 20, allowing studies of its antiproliferative effect. Interestingly complex $\mathbf{2 0}$ is highly cytotoxic on cell lines with different p53 status including those with mutated p53 which are associated with cancers with poor prognosis. Product $\mathbf{2 0}$ is not toxic in vivo and is beneficial on BDF1 mice with L1210 leukemia, with survival increasing from 13.7 to 17.5 days at doses of $26 \mu \mathrm{g} / \mathrm{kg}^{50}$

This overview reveals the number and diversity of initiatives being explored using conjugates of ferrocene. Given that many biological studies both in vitro and in vivo have 
focused on the ferrocifens, where we also have more mechanistic data, this topic will now be covered in greater detail.

\section{The ferrocifens and other members of the metallocifen family}

The ferrocifen family is so-called because the first examples in the series were ferrocenyl analogues of hydroxytamoxifen (series A ; Chart 4). The interest in this particular set of complexes prompted an SAR study aimed, on the one hand, towards finding more active molecules and, on the other hand as a route to understanding their mechanism of action. This family is comprised of about 200 complexes that can be placed in six groups. Series C and D have in common the skeletal motif phenyl-but-1-ene-ferrocene in either the open or ansa series. This SAR study led to the extension to complexes of other metallocenes (series B), with two sidechains (series G), with a ferrocenyl unit attached to the sidechain (series E), and more recently to hybrid SAHA-ferrocifens (series F) and complexes with modified alkyl chain (series $\mathrm{H}$ ). 


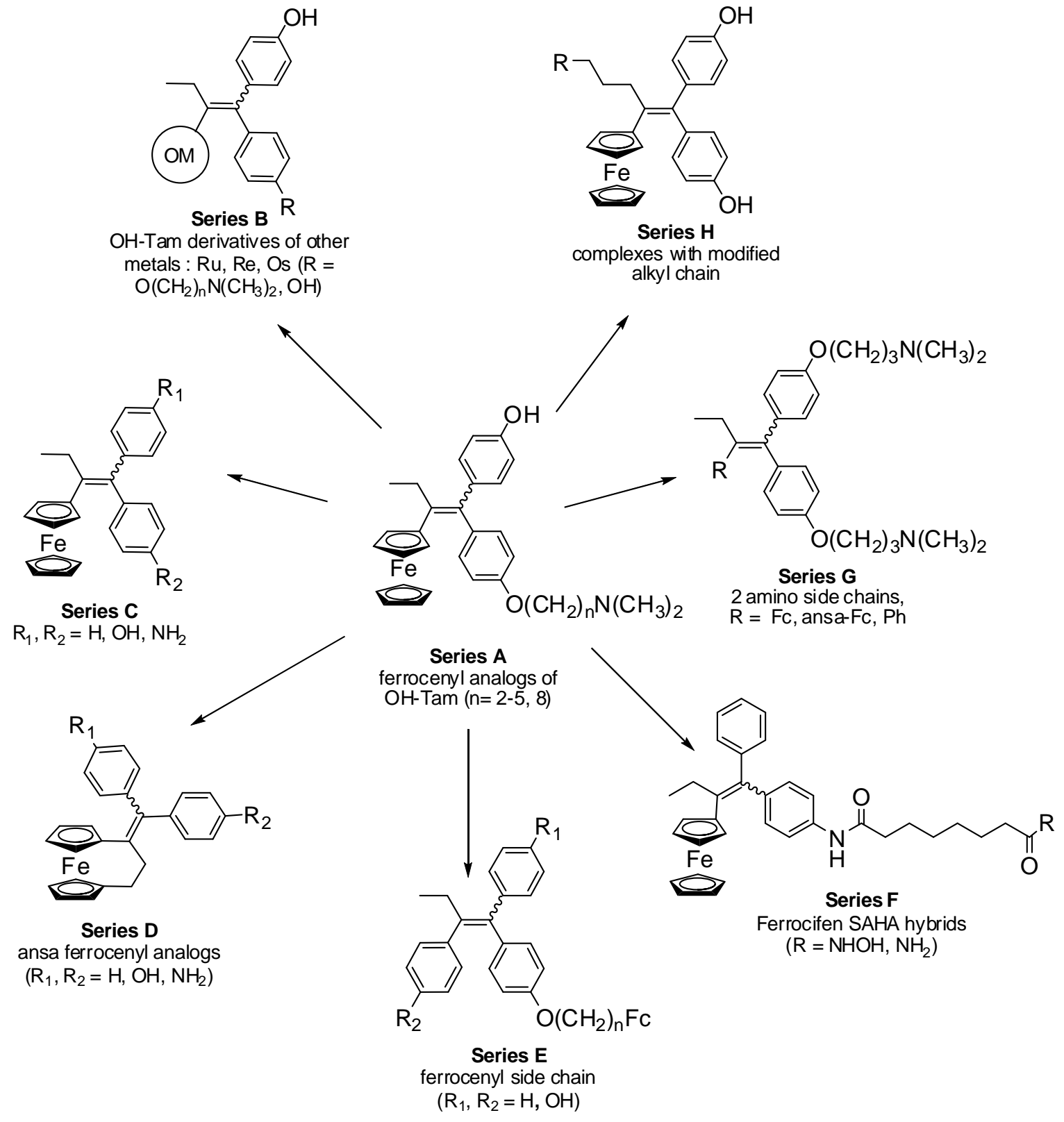

Chart 4 : Selected ferrocifens

\subsection{Synthesis of complexes with a hydroxy-phenyl-but-1-ene skeleton}

Two synthetic routes have been developed for access to these molecules. The first method (Scheme 1) involves addition of an organolithium reagent $\left(\mathrm{MeOC}_{6} \mathrm{H}_{4} \mathrm{Li}\right)$ to an ester (2-ethyl-2 ferrocenyl acetate) to give the dimethylether derivative, followed by its demethylation using $\mathrm{BBr}_{3}$ which furnishes the ferrocenyl diphenol (Fc-diOH, 2). ${ }^{28}$ 


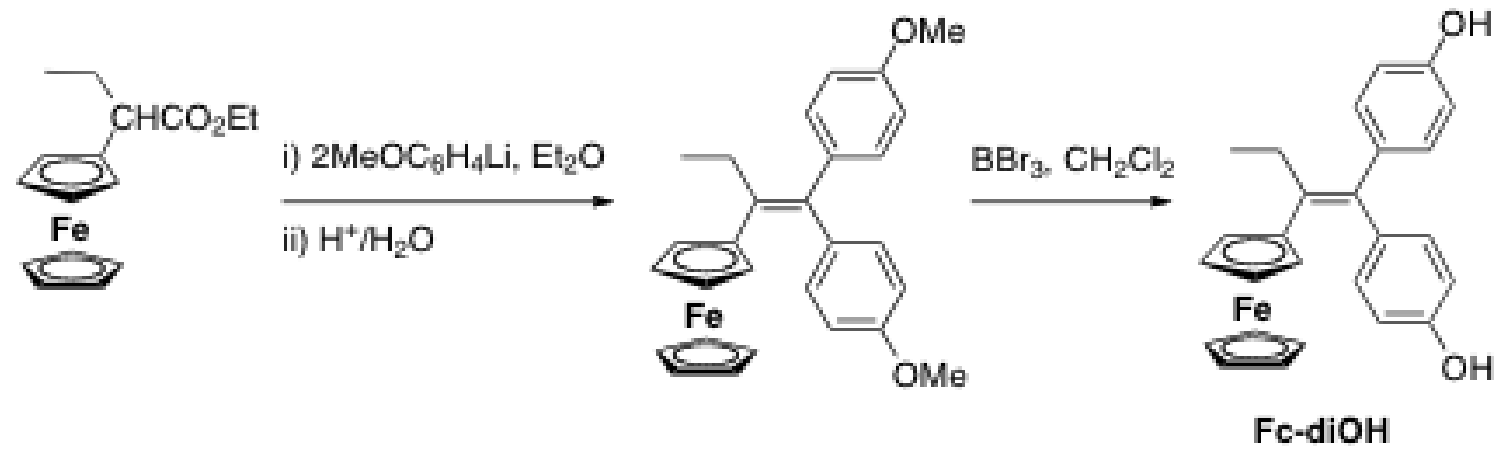

Scheme 1 : First pathway of synthesis of Fc-diOH

One of the inconveniences of this method is the necessity to protect and then deprotect functional groups that react with lithium reagents. However, this problem can be overcome by taking advantage of the McMurry coupling of two different ketones ${ }^{51}$ whereby Fc-mono and diOH can be obtained in good yield (Scheme 2, 53\% for Fc-diOH) ${ }^{52}$ The benefit of this method is its tolerance to many functional groups, and the majority of the ferrocifen family including the ansa series have been prepared by this method.

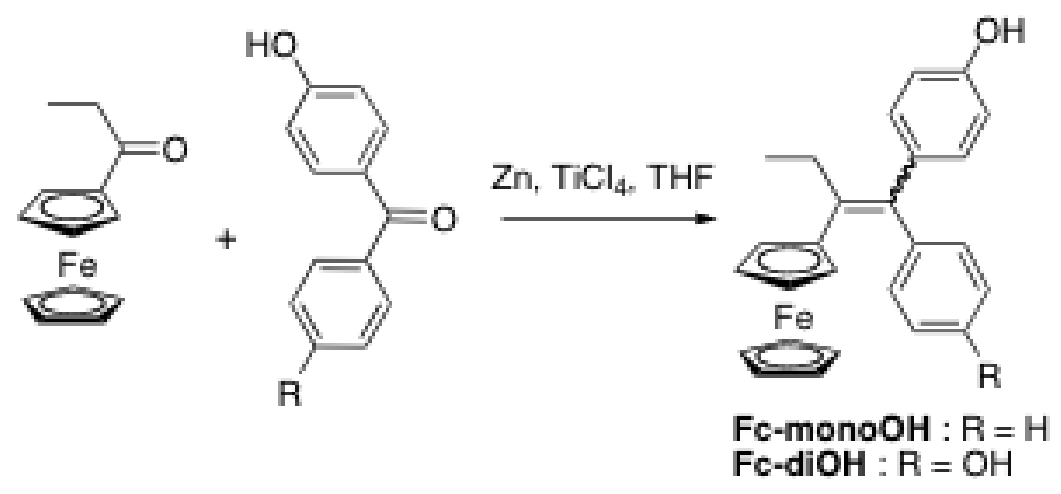

Scheme 2 : Synthesis of Fc-monoOH and Fc-diOH via a McMurry cross coupling reaction

The addition of a basic side-chain (with lengths ranging from 2-5, or 8 carbons) to one of the two hydroxyl groups can be carried out in two different ways (Scheme 3). Route A involves deprotonation with sodium ethoxide followed by treatment with the chloroalkyldimethylamine derivative $\left[\mathrm{Cl}\left(\mathrm{CH}_{2}\right)_{\mathrm{n}} \mathrm{NMe}_{2}\right]$, where the systems $\mathrm{n}=2$ or 3 are commercially available. The corresponding Fc-OH-Tam complexes are obtained as a 50/50 $E / Z$ mixture, and the disubstituted system is a minor product. ${ }^{28}$ In the other cases, $(\mathrm{n}=4,5,8)$ the synthesis (route $\mathrm{B}$ ) begins by alkylation of the dihydroxybenzophenone using the corresponding dichloroalkane $\left[\mathrm{Cl}\left(\mathrm{CH}_{2}\right)_{\mathrm{n}} \mathrm{Cl} ; \mathrm{n}=4,5,8\right]$ that yields both the mono and dialkylated ketones. Now, McMurry coupling with propionylferrocene gives the halogenated complexes which, in the final step, react with dimethylamine hydrochloride in an autoclave to furnish the required products. ${ }^{29,30}$ 

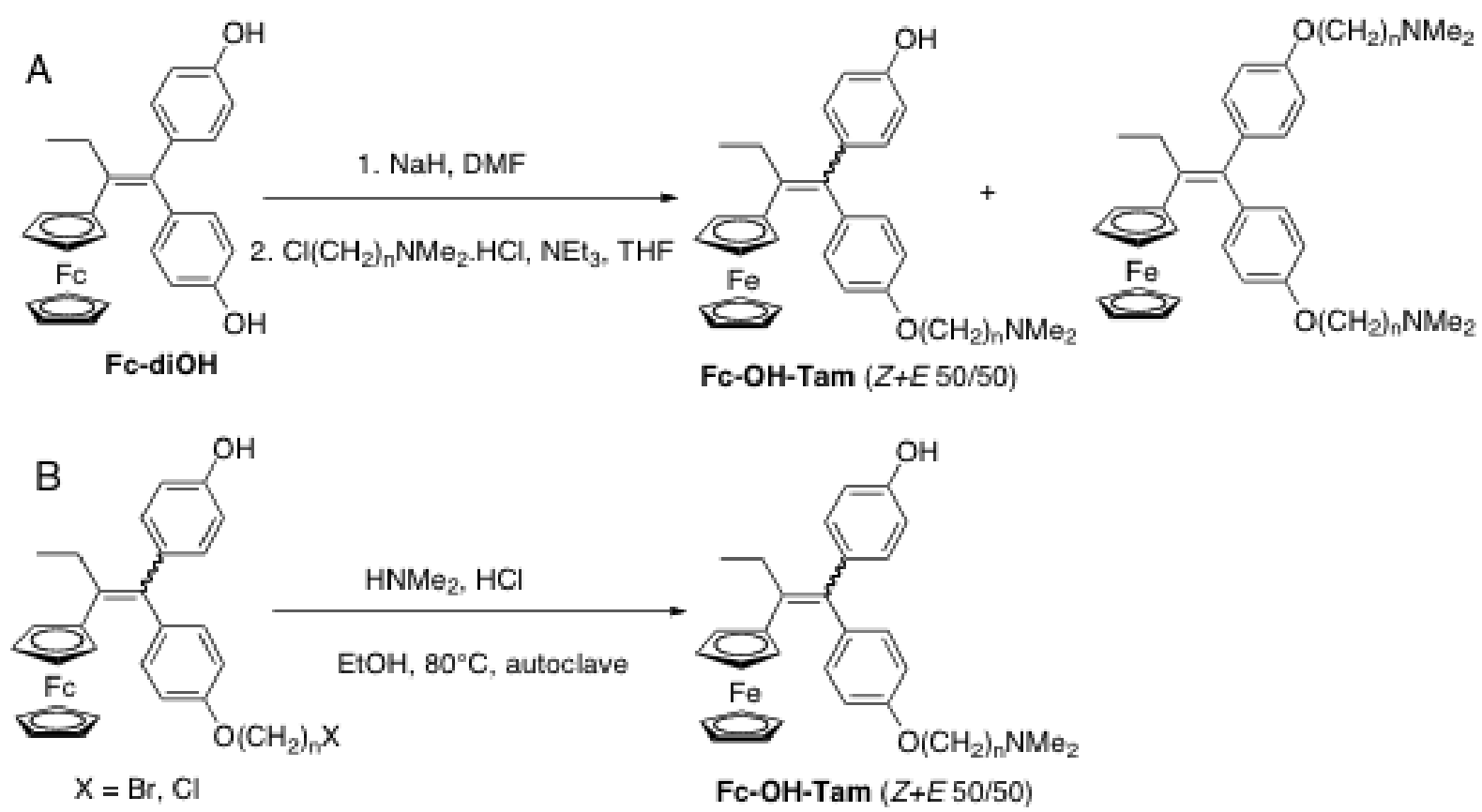

Scheme 3 : Synthetic routes to ferrocifens with amino side chains of various length

In certain cases, it is possible to separate the $Z$ and $E$ isomers ; however, in protic media isomerisation to an approximately 50/50 mixture is rapid, consequently it is the mixture that has been used in the biological studies. These complexes have a higher lipophilicity than $\mathrm{OH}$ Tam itself (cf Table 1) and is enhanced with increased chain length allowing in vitro easier entrance into cells. They are soluble in organic solvents, but much less so in the aqueous media encountered in biology. Thus, to study their effects in vitro on cell cultures, $1 \mathrm{mM}$ solutions are prepared in DMSO then diluted in the culture medium (final maximum concentration of DMSO of 0.5\%). Selected ferrocifens are shown in Chart 5.

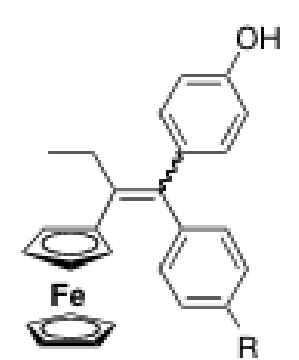

Fc-monoOH : R = H $\mathrm{Fc}$-diOH $: \mathrm{R}=\mathrm{OH}$

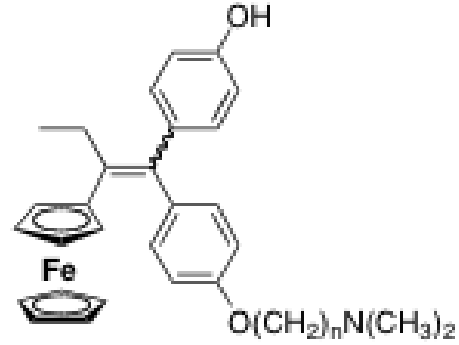

Fc-OH-Tam[3]: $\mathrm{n}=3$ Fc-OH-Tam[4]: $n=4$

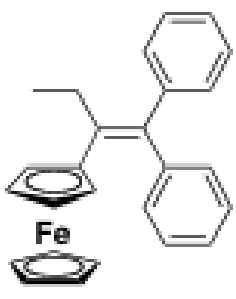

Fc-diPh

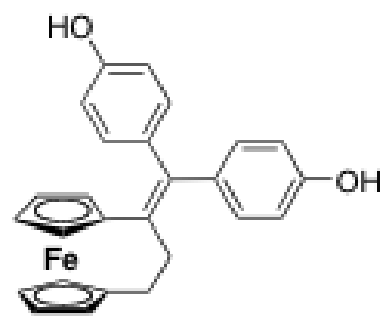

ansa-Fc-diOH

Chart 5: Selection of ferrocifens of interest 


\subsection{A study of the interactions of the ferrocifens with the alpha and beta forms of the estradiol receptor $(E R \alpha$ and $E R \beta)$}

The estrogenic effects of hydroxy-tamoxifen, and more generally of SERMs, are widely described as being mediated by their interactions with the two forms, $\alpha$ and $\beta$, of the estrogen receptor. The presence of ER $\alpha$ in breast tumours is a marker leading to their classification as hormone-dependent tumours, and is a good indicator of their positive response to hormone therapy. However, in the case of ER $\beta$, almost 20 years after its discovery by Gustafsson, and even after numerous studies, its exact role has still to be elucidated. ${ }^{53}$ From the beginning of the studies on Fc-OH-Tam and Fc-diOH the Relative Binding Affinity (RBA) has shown the possibilities of association with both the $\alpha$ et $\beta$ isoforms of the estrogen receptor. The RBAs of ferrocenyl complexes have been systematically studied for their effect on the growth of the hormone-dependent cancer cells MCF-7. In general, the complexes maintain an affinity for $\mathrm{ER} \alpha$ and ER $\beta$ even if the measured values are lower than for OH-Tam (Table 1).

Table 1 : Lipophilicity and Relative binding affinity (RBA) values for the estrogen receptor ( $\alpha$ and $\beta$ forms) of some ferrocifens ${ }^{29,30}$

\begin{tabular}{|c|c|c|c|}
\hline & \multicolumn{2}{|c|}{$\mathrm{RBA}(\%) 0^{\circ} \mathrm{C}, 3 \mathrm{~h} 30^{\text {a) }}$} & \multirow{2}{*}{ LogPo/w } \\
\hline OH-Tam & $\mathrm{ER} \alpha$ & $\mathrm{ER} \beta$ & \\
\hline Fc-OH-Tam[3] & $38.5 \pm 3$ & 24 & $3.2(\mathrm{Z}) ; 3.4(\mathrm{E})$ \\
\hline Fc-OH-Tam[4] & $11.5 \pm 3$ & $12 \pm 1$ & $4.3(\mathrm{Z}) ; 4.5(\mathrm{E})$ \\
\hline Fc-monoOH & $5 \pm 0.2$ & $11 \pm 1$ & $4.0(\mathrm{Z}) ; 4.2(\mathrm{E})$ \\
\hline Fc-diOH & $9.6 \pm 0.9$ & 11 & $6.1(\mathrm{Z}) ; 6.2(\mathrm{E})$ \\
\hline
\end{tabular}

a) mean of 2 experiments (when available) \pm standard error

For those complexes bearing an amino chain it has been shown that the best antiestrogenic effect is found with a 3 or 4 carbon side-chain rather than the 2-carbon one in $\mathrm{OH}$-Tam. This has been rationalised in terms of the greater volume of a ferrocenyl moiety thus requiring a longer arm than is needed for a phenyl group. This antiestrogenic effect is observed at low concentrations and leads to inhibition of the growth of MCF-7 cells practically equivalent to that seen for OH-Tam, but is suppressed upon addition of a low concentration of estradiol $(10 \mathrm{nM})$, and at higher concentrations the complex becomes cytotoxic. In the case of complexes devoid of an amino chain, such as Fc-diOH or FcmonoOH, one sees at low concentrations $(0.1 \mu \mathrm{M})$ an estrogenic effect similar to that 
observed with the corresponding purely organic phenols. When the concentration of incubation increases we discern cytotoxic effect attributable to the presence of the ferrocene.

We can say that the construction of these complexes based on the structure of $\mathrm{OH}$ Tam raises hopes for the possibility of association with the receptor. Molecular modelling studies have shown that Fc-OH-Tam $(n=3,4)$ forms an anti-estrogenic type association with $\mathrm{ER} \alpha$, present in MCF-7 (Figure 1). The interaction of Fc-OH-Tam with ER $\beta$ is also antiestrogenic, but with Fc-diOH, agonist-type binding is favoured. The steric hindrance generated by the basic chain stabilises the indicated conformation via an association with Asp351 ; this prevents the recruitment of the peptide effectors to trigger an estrogenic effect as occurred with Fc-diOH in a different conformation by association between helices $\mathrm{H} 12$ and H4.

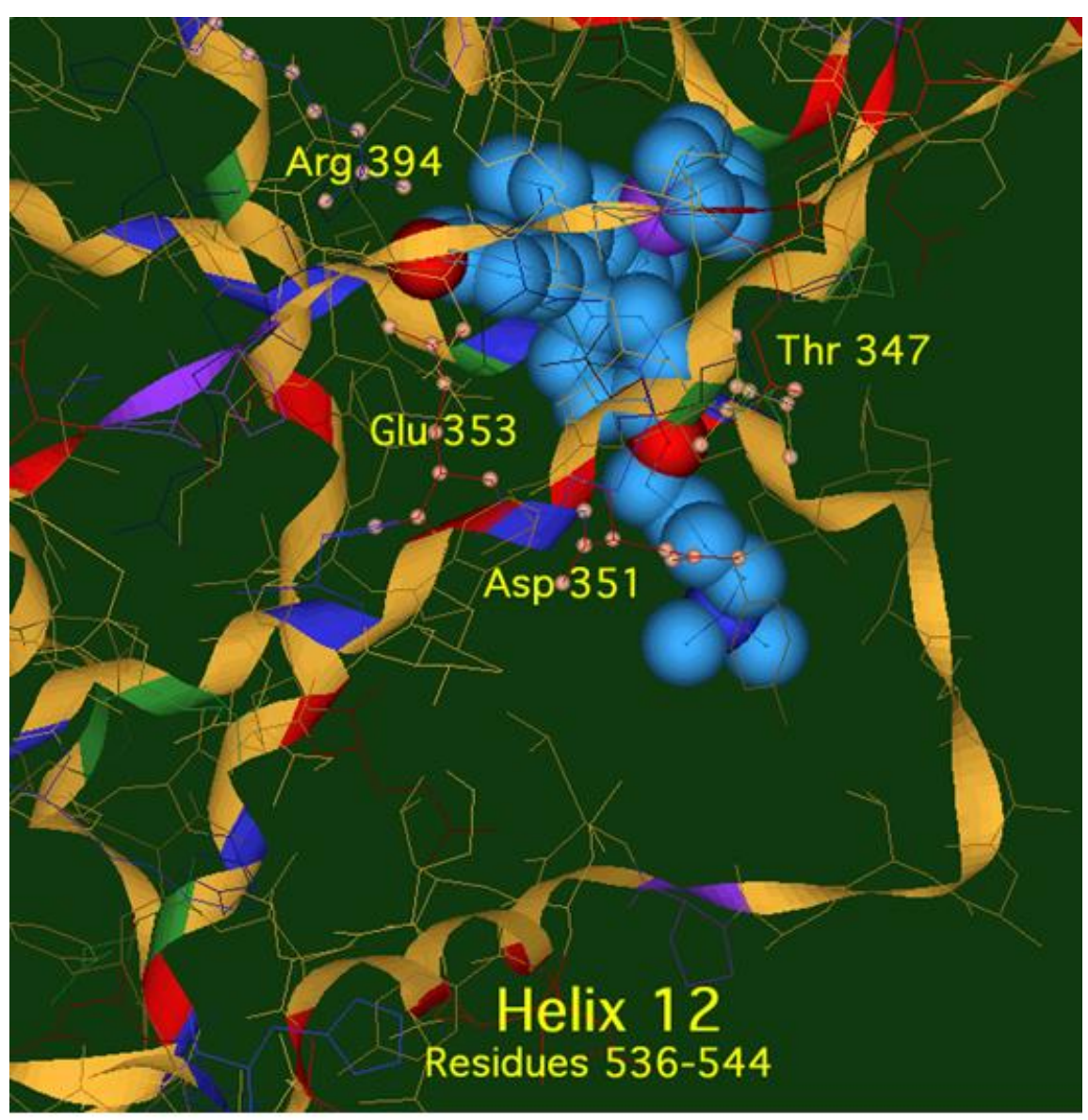

Figure 1 : Image of Fc-OH-Tam $(n=4)$ docked in the ligand binding domain (LBD) of ER $\alpha$ with an antagonist conformation. (Adapted from the LBD X-ray structure) ${ }^{54}$ 
These studies show that the active site of ER $\alpha$ can accommodate molecules in which the planar aromatic ring in the $\alpha$ position has been replaced by the bulkier ferrocenyl moiety. ${ }^{29,} 30$ This possibility has been verified for other tamoxifen-like analogues where diphenol derivatives of other metallocenes (ruthenocene, osmocene, cyclopentadienyl rhenium tricarbonyl), also maintain an affinity for the estradiol receptor. These tamoxifen-like complexes have an antiestrogenic antiproliferative effect on MCF-7 cells, identical to that of the ferrocifens where the mono and diphenolic complexes have an estrogenic effect. These complexes do not have an antiproliferative effect on the hormone-independent breast cancer cells (MDA-MB-231) at an incubation concentration of $1 \mu \mathrm{M}$ and distinguishes them from Fc-OH-Tam; clearly, the presence of iron engenders a particular cytotoxicity.

The possibility of interaction of organometallic complexes with estrogen receptors is not matched by their behaviour with androgens. Thus, the incorporation of a ferrocenyl substituent at the $17 \alpha$ position in ethynyl-dihydrotestosterone or dihydrotestosterone (DHT), or on nilutamide, a non-steroidal antiandrogen, results in the loss of recognition of the organometallic compound by the receptor. This may be rationalised in terms of the structure of the active site of the androgen receptor that cannot accommodate such a bulky substituent at the $17 \alpha$ position of DHT ; this contrasts with the flexibility of ER $\alpha$ that has available space because of the flexible methionines present. ${ }^{34,55}$

One of the suggested approaches concerning the possible role of ER $\beta$ was that of redox activity. In this context, we have studied the antiproliferative effect of two tamoxifenlike ferrocifens (Fc-OH-Tam[3] and Fc-OH-Tam[4]) on a series of cancer cells where the presence or absence of ER $\alpha$ or ER $\beta$ has been established by quantification of their level of mRNA. 
Table 2 Antiproliferative effect of OH-Tam and Fc-OH-Tam with $n=3$ or 4 on various cell lines and comparison with their $\mathrm{ER} \alpha$ and $\mathrm{ER} \beta$ content.

\begin{tabular}{|c|c|c|c|c|c|}
\hline Cell line $^{\text {a }}$ & $\begin{array}{c}\text { ER } \alpha \\
\text { status }\end{array}$ & $\begin{array}{c}\mathrm{ER} \beta \\
\text { status }\end{array}$ & \multicolumn{3}{|c|}{$\%$ remaining cells (incubation $1 \mu \mathrm{M}, 5$ days) } \\
\hline & & & $4-O H-T a m$ & Fc-OH-Tam[3] & Fc-OH-Tam[4] \\
\hline MCF-7 & ++ & + & $75 \pm 2$ & $62 \pm 2$ & $58 \pm 0$ \\
\hline $\begin{array}{c}\text { MDA-MB- } \\
231\end{array}$ & - & +++ & $94 \pm 3$ & $37 \pm 6$ & $44 \pm 6$ \\
\hline PC-3 & $+/-$ & ++ & $100 \pm 1$ & $36 \pm 14$ & $35 \pm 5$ \\
\hline NCI-ACHN & - & +++ & $100 \pm 1$ & $2.5 \pm 0.5$ & $2,5 \pm 0.5$ \\
\hline NCI-786 & - & - & $98 \pm 5$ & $3 \pm 0$ & $3.5 \pm 0.5$ \\
\hline
\end{tabular}

a) breast cancer cells : MCF-7, MDA-MB-231 ; prostate : PC-3 ; kidney cancer cells : NCIACHN, NCI-786 ; b) mean of two experiments \pm standard error

We see in Table 2 that, at a concentration of $1 \mu \mathrm{M}$, OH-Tam and two ferrocifens are active on the MCF-7 line containing ER $\alpha$. In the case of PC-3 where ER $\alpha$ is only at the limit of detection, but $E R \beta++$ is clearly present, there is a significant antiproliferative effect with Fc-OH-Tam ( $n=3$ and 4). On the cell line NCI-ACHN, which contains ER $\beta$ but not ER $\alpha$, there is a very strong antiproliferative effect. This is also the case on the cell line NCI-786 where $\operatorname{ER} \alpha$ and $\beta$ are absent. Thus, one can clearly state that $\operatorname{ER} \beta$ does not play an essential role in the antiproliferative effects of the ferrocifens.

\subsection{An SAR study of the ferrocifen family}

The antiantiproliferative effect of these complexes was first of all studied by determining their $\mathrm{IC}_{50}$ values on cancer cells (MDA-MB-231, MCF-7, PC-3) but also in certain cases on noncancerous cells. The first characteristic of these complexes is that their cytotoxicity is much higher on cancer cells than on normal cells. This has been shown on melanocytes (NHEM, neonatal human epidermal melanocytes) ${ }^{56}$ and astrocytes ${ }^{57}$ for Fc-diOH and Fc-OH-Tam and on GBM cells (glomerular basement membrane) for Fc-diPh. ${ }^{58}$ This allowed us to show that the ferrocenyl - double bond - phenol motif was essential for expression of a strong cytotoxic effect. Ferrocene itself is not toxic for the cells $\left(\mathrm{IC}_{50}=150 \mu \mathrm{M}\right)$, and shifting the ferrocenyl unit to the end of the side-chain leads to much less toxic complexes (series E; IC $_{50}$ around 7.5 $\mu \mathrm{M})$. This is the case even when the double bond is replaced by an $\mathrm{sp}^{3}$ carbon $\left(\mathrm{IC}_{50}=3-4\right.$ $\mu \mathrm{M}){ }^{59}$ This approach allowed us to identify that, in addition to the tamoxifen-like systems, a series of mono- and di-substituted complexes bearing $\mathrm{OH}$ and/or $\mathrm{NH}_{2}$ substituents have a strong antiproliferative effect on MDA-MB-231 cells (Table 3). ${ }^{60,61}$ 
Table 3 IC $_{50}$ values of a selection of complexes in the ferrocenyl acyclic and ansa series

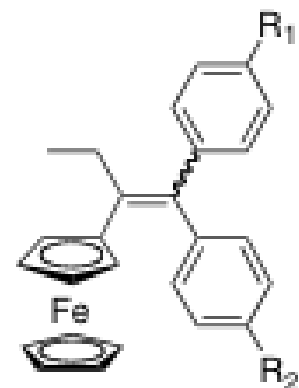

acyclic series

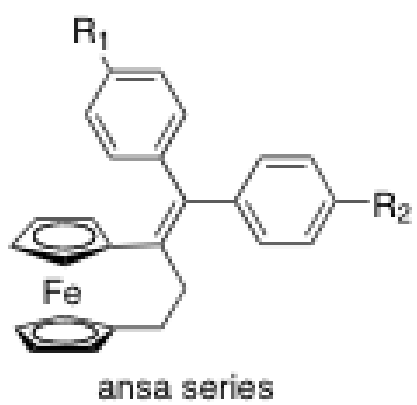

\begin{tabular}{|c|c|c|c|}
\hline $\mathrm{R}_{1}$ & $\mathrm{R}_{2}$ & $\mathrm{IC}_{50}(\mu \mathrm{M})$ on MDA-MB-231 cells \\
\hline & & acyclic series & ansa series \\
\hline $\mathrm{OH}$ & $\mathrm{O}\left(\mathrm{CH}_{2}\right)_{3} \mathrm{~N}\left(\mathrm{CH}_{3}\right)_{2}$ & 0.5 & - \\
\hline $\mathrm{OH}$ & $\mathrm{OH}$ & $0.64 \pm 0.06$ & $0.089 \pm 0.006$ \\
\hline $\mathrm{OH}$ & $\mathrm{H}$ & $1.54 \pm 0.13$ & $0.47 \pm 0.06$ \\
\hline $\mathrm{NH}_{2}$ & $\mathrm{H}$ & $0.86 \pm 0.04$ & $0.21 \pm 0.03$ \\
\hline $\mathrm{NH}_{2}$ & $\mathrm{NH}$ & $\mathrm{n} .0 .^{b}$ & $0.05 \pm 0.01$ \\
\hline $\mathrm{NH}_{2}$ & $\mathrm{OH}$ & $0.55 \pm 0.05$ & $0.061 \pm$ \\
& & & 0.005 \\
\hline $\mathrm{H}$ & $\mathrm{H}$ & $7.5 \pm 0.7^{\mathrm{c}}$ & - \\
\hline
\end{tabular}

a) values from ref ${ }^{61}$ after 5 days of incubation, mean of 2 experiments \pm standard error; b) molecule not obtained ; c) $\mathrm{IC}_{50}$ value on HL-60 $=1.04 \mu \mathrm{M}^{62}$

More recently, we have synthesised a series of ansa complexes in which the two cyclopentadienyl rings are linked via a three-carbon bridge. ${ }^{33}$ The IC $_{50}$ values obtained for these complexes are very clearly lower than for their open-chain homologues. It has also been noted that the dose-effect curves of the complexes in these two series are different, in particular for the diphenol complexes which have been studied on the NCI panel of 60 cell lines. For Fc-diOH the curves have a single slope, whereas for ansa-Fc-diOH the curves exhibit two slopes connected by a plateau. ${ }^{61}$ These two compounds are the most active against those cancers (leukemia, central nervous system, renal cancer) for which there are no satisfactory treatments. Moreover, comparison with the 171 molecules in the NCI database reveals that the behaviour of these molecules is different from those already in the database. ${ }^{61}$ This study led to the identification of 3 hits, Fc-diOH, Fc-OH-Tam and ansa-Fc-diOH whose mechanisms of action and effects in vivo have been studied.

\subsection{Effects of the ferrocifens at the cellular level.}

One of the common characteristics of the ferrocifens is that as concentrations approach 
the $\mathrm{IC}_{50}$ values they show the arrest of cellular growth by senescence whenever this is possible, and not cell death by apoptosis. This senescence is associated with the observation of a cytostatic effect of the complexes which expresses itself by a flattening and an increase in size of the cells incubated at a concentration of about $1 \mu \mathrm{M}$ with Fc-OH-Tam, ${ }^{64}$ Fc-diOH and even lower with ansa-Fc-diOH. ${ }^{63}$ This induction of senescence was ascertained with SA- $\beta$ galactosidase staining and senescence associated secreting phenotype (SASP) as measured by the secretion of IL-8 and TNF- $\alpha$, in cancer cell models characterised by various sensitivities to pro-apoptotic stimuli (MDA-MB-231, MCF-7, U373, Hs683, B16F10). ${ }^{63,64}$ The secretion of these cytokines may be related to AP-1 transcription factor activity at $1 \mu \mathrm{M}$ but not at 10 $\mu \mathrm{M}$. This observation is in accord with the result observed in vivo after innoculation of nude mice with B16F10 cells that are inactivated in the presence of 1 or $10 \mu \mathrm{M}$ of ansa-FcdiOH. In effect, none of the animals having received cells treated with $1 \mu \mathrm{M}$ of complex developed tumours, whereas two out of five animals having received cells treated with $10 \mu \mathrm{M}$ of complex did so. Despite a different oxidation pathway in terms of generation of quinone methides (vide infra) the two complexes induce similar cellular changes related to senescence induction in those cell models. At elevated concentrations $(5-25 \mu \mathrm{M})$ the complex Fc-OHTam induces a rapid rounding of the cancerous cells (melanomas, MDA-MB-231, MCF-7) followed by their detachment. ${ }^{56,65}$ This effect can be related to the presence of the amino chain which, when protonated at physiological pH, apparently behaves like a detergent. It is also seen with tamoxifen derivatives of other metallocenes (ruthenocene, osmocene) ${ }^{66}$ In these variations of cell cycles we observe different behaviour as a function of the incubation concentration. Fc-diOH at a concentration of $1 \mu \mathrm{M}$ and ansa-Fc-diOH at a concentration of $10 \mathrm{nM}$ lead after $48 \mathrm{~h}$, to an accumulation of cells in the S phase (on MDA-MB-231 and 9L cells). At a more elevated concentration of ansa-Fc-diOH $(0.5-2 \mu \mathrm{M})$ one sees an accumulation of $9 \mathrm{~L}$ cells in the G0/G1 phase and about $30 \%$ of the cells in apoptosis. ${ }^{67}$ Incubation of $10 \mu \mathrm{M}$ of Fc-diOH and of ansa-Fc-diOH with mouse melanoma cells B16F10 led to $80 \%$ apoptosis. ${ }^{63}$ One should also note the particular behaviour of the complex Fc-diPh which lacks the phenolic group (Chart 5). This complex has an elevated cytotoxicity on the leukemia cells HL-60 $\left(\mathrm{IC}_{50}=1.04 \mu \mathrm{M}\right)$ but a more modest one on MDA-MB-231 cells ( $\mathrm{IC}_{50}$ $=7.5 \mu \mathrm{M})$. At a concentration of $1 \mu \mathrm{M}$ it induces apoptosis of HL-60 with an accumulation of cells in the G0/G1 phase. ${ }^{58}$ This singular behaviour is probably associated with the production of ROS (see below). It appears then that the type of inactivation or cell death pathway (senescence, apoptosis) varies according to the complexes, the cell lines and the dosages used. 
We note, however, that the special feature of the ferrocifens is their efficacy, by senescence at low dosages, on cell lines resistant to apoptosis.

\subsection{Mechanisms of action related to the redox properties of ferrocene}

The particular antiproliferative effects of the ferrocifens appear to be associated with the unique redox properties of ferrocene, that is to say a reversible oxidation of $\mathrm{Fe}(\mathrm{II})$ to $\mathrm{Fe}(\mathrm{III})$ at a potential around $0.40 \mathrm{~V} .^{68}$ This behaviour differs from that of ruthenocifen whose oxidation rapidly becomes irreversible, and of osmocifen whose oxidation is always irreversible. This turns into a large difference in the acidity of the phenolic protons. ${ }^{66}$ Ruthenocifen and osmocifen can also be oxidised in their corresponding quinone methides but at a lower rate than ferrocifen (18 times to 3 times depending on the complexes). This could be associated with the redox potential of the three metallocenes $(0.47,1.03,0.83 \mathrm{~V}$, respectively for ferrocene, ruthenocene and osmocene), which results in an easier oxidation of ferrocifens than ruthenocifens and osmocifens. ${ }^{66}$

\subsubsection{Production of reactive oxygen species (ROS)}

The first studies of the antiproliferative effects of ferrocenyl complexes were carried out by Köpf-Maier and Neuse on ferrocenium salts. ${ }^{69}$ Subsequently, this was repeated by Osella who showed by EPR that the generation of reactive oxygen species (ROS) is implicated in this cytotoxicity and more specifically that $\mathrm{OH}^{*}$ radicals can be produced starting from $\mathrm{Fe}(\mathrm{II})$ by a Fenton-type reaction. ${ }^{70}$ Even though the $\mathrm{IC}_{50}$ values of these complexes are very much larger than those of the ferrocifens ( $250 \mu \mathrm{M}$ versus $0.5 \mu \mathrm{M}$ ), the assumption that ROS are involved in the toxicity of the ferrocifens is a factor that has been explored. The quantities of ROS produced after 10 minutes incubation of MDA-MB-231 cells in the presence of $1 \mu \mathrm{M}$ of several representative complexes and their precursors (ferrocene and $\mathrm{OH}-\mathrm{Tam}$ ) are shown in Figure 2.

It shows that ferrocene $(\mathrm{Fc})$ and hydroxytamoxifen $(\mathrm{OH}-\mathrm{Tam})$ do not produce ROS at the $1 \mu \mathrm{M}$ incubation concentration but all the ferrocenyl complexes do so. The effect of ROS on the toxicity of the ferrocifens has been demonstrated by the fact that addition of antioxidants such as $\mathrm{N}$-acetyl cysteine or vitamin $\mathrm{E}$ lead to loss of their antiproliferative effect. $^{64,71}$ In contrast, production of ROS is not linked to the presence of a phenol and there is no correlation between the $\mathrm{IC}_{50}$ values and the quantity of ROS measured for the complex. This is particularly true for the complex Fc-diPh, which is one of the two compounds that produce the most ROS but which shows only medium cytotoxicity towards MDA-MB-231 
$\left(\mathrm{IC}_{50}=7.5 \mu \mathrm{M}\right)$. This production of ROS could be the origin of the toxicity of this complex on HL-60 leukemia cells that are sensitive to apoptosis. In effect, this complex that lacks the phenolic group cannot lead to formation of a quinone methide that could play a decisive role in the toxicity of the most active complexes (see below) and leads to cell death by apoptosis and not to inactivation via senescence as with the other complexes. One must emphasise that the protocol used to measure the ROS is important. Thus, a 30 min pre-incubation of the cells in the presence of a solution of $\mathrm{H}_{2}$ DCFDA $(10 \mu \mathrm{M})$, followed by rinsing, then incubation in the presence of the tracer $(1 \mu \mathrm{M})$ allows observation of the generation of ROS, ${ }^{64,65}$ but when one incubates the cells in the presence of the complexes before adding $\mathrm{H}_{2}$ DCFDA formation of ROS is not observed. ${ }^{62}$ This is probably related to the fact that ROS are very reactive species and so $\mathrm{H}_{2}$ DCFDA, the probe used to detect them, needs to be present in cells at the time of their formation.

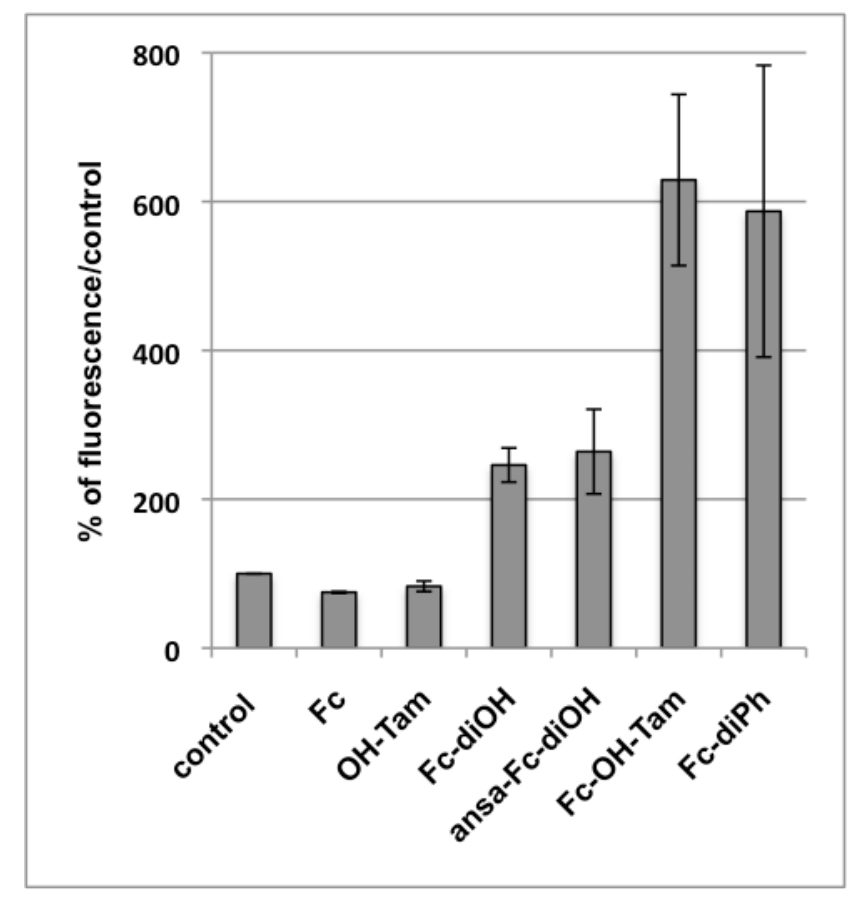

Figure 2 : ROS production in MDA-MB-231 ( $1 \mu \mathrm{M}, 10 \mathrm{~min}, \mathrm{H}_{2}$ DCFDA as fluorescent probe, mean of two experiments)

\subsubsection{Formation of quinone methides}

A redox process involving two electrons and two protons leading to formation of a phenoxy radical and then a quinone methide has been suggested as being the origin of the high toxicity of these molecules (Scheme 4). ${ }^{68}$ This is based on the electrochemical oxidation of Fc-monoOH which shows that the reversible oxidation of ferrocene becomes irreversible in the presence of pyridine or imidazole; it is accompanied by deprotonation of the phenol and 
leads to formation of the quinone methide. Each step in this reaction scheme has been confirmed by electrochemical and EPR studies of the particular complex stabilised with two ortho methyl substituents in the phenol $\left(\mathrm{R}=\mathrm{CH}_{3}\right)$. ${ }^{68,72}$
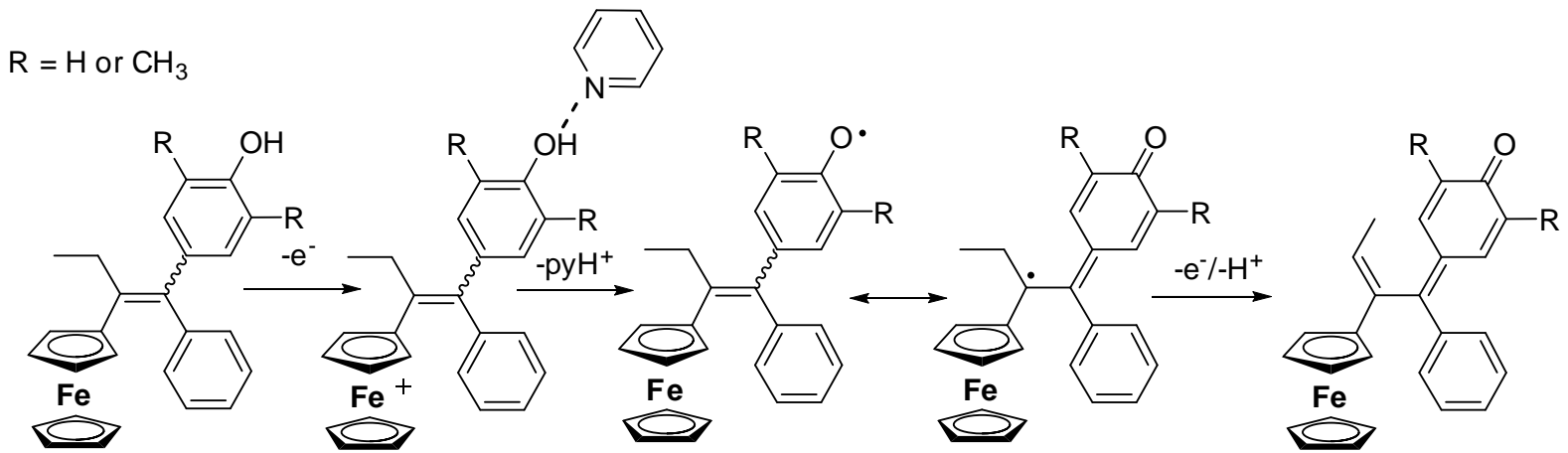

Scheme 4 : Mechanism for the formation of quinone methides ${ }^{68,72}$

The considerable strength of the ROS signal suggests that it could play a role in the first step, that is to say the oxidation of $\mathrm{Fe}(\mathrm{II})$ to $\mathrm{Fe}(\mathrm{III})$. The quinone methides of Fc-OHTam, Fc-mono and diOH have been prepared by chemical oxidation using $\mathrm{Ag}_{2} \mathrm{O}$. An X-ray crystal structure of the quinone methide derived from the phenol stabilised by two methyl substituents (Scheme 4 ; $\mathrm{R}=\mathrm{CH}_{3}$ ) has been obtained. ${ }^{73}$ Moreover, a study of the metabolism of Fc-OH-Tam, Fc- mono and diOH using rat liver microsomes shows the formation of three major metabolites (Scheme 5): (1) the quinone methide (oxidation product), (2) the indene obtained by cyclisation of the quinone methide in an acidic medium and (3) the allylic alcohol (hydroxylation product). ${ }^{74}$

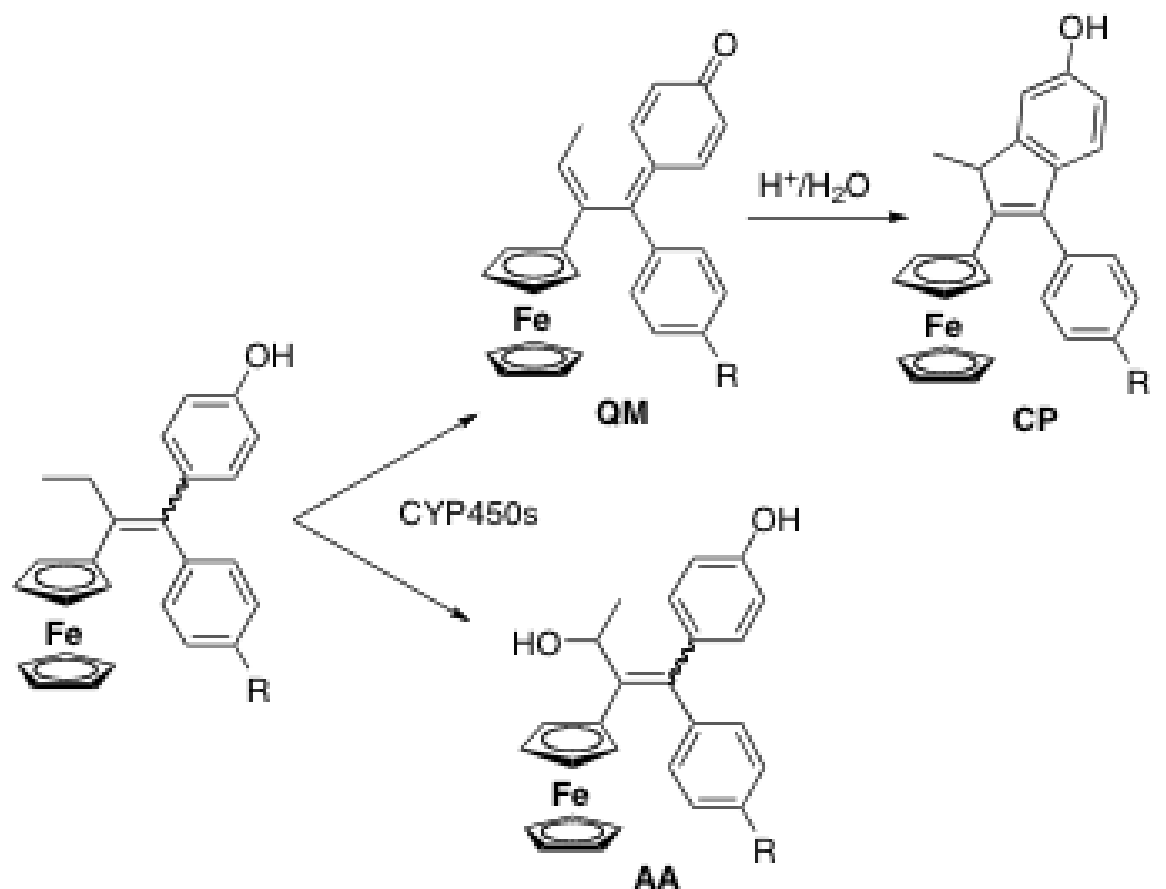


Scheme 5 : Main metabolites formed upon oxidation of ferrocifens by rat microsomes (CYP 450). $\mathrm{R}=\mathrm{H}, \mathrm{OH}, \mathrm{O}\left(\mathrm{CH}_{2}\right)_{3} \mathrm{~N}\left(\mathrm{CH}_{3}\right)_{2} \cdot{ }^{74}$

In the case of Fc-OH-Tam, two additional metabolites are obtained, Fc-diOH and the demethylated complex. Interestingly, it has been shown that the vinyl alcohol, a close relative of the allylic alcohol obtained, exhibits a strong antiproliferative effect $\left(\mathrm{IC}_{50}=0.2 \mu \mathrm{M}\right)$. Since we know that P450 cyctochromes exist in cancerous cells, such a metabolite could play a role in the toxicity of the ferrocifens.

The case of ansa-Fc-diOH is different since chemical oxidation or incubation in the presence of microsomes does not lead to formation of the corresponding quinone methide, but this does not prevent this complex from having one of the lowest $\mathrm{IC}_{50}$ values (89 $\mathrm{nM}$ on MDA-MB-231). In an electrochemical study it was not possible to detect the QM from this complex, nevertheless the complex does undergo an initial oxidation of $\mathrm{Fe}$ (II) to $\mathrm{Fe}(\mathrm{III})$. One can rationalise this behaviour in terms of the steric strain imposed by the three-carbon bridge that prevents the two cyclopentadienyl rings from becoming parallel and does not allow the planarity required for formation of a quinone methide. This active species may be the radical precursor to the QM, as shown below (Chart 6).

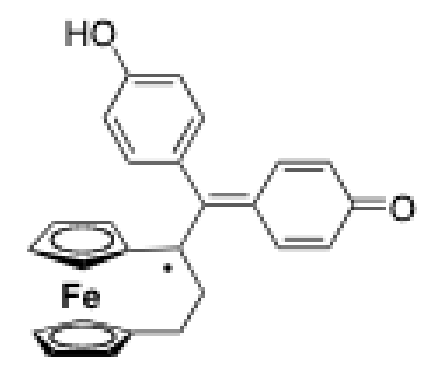

Chart 6 : Quinone methide radical derived from ansa-Fc-diOH

In all cases the quinone methides and their radical precursors are potentially very reactive intermediates and one could regard the ferrocifens as pro-drugs that allow the generation of these cytotoxic entities in the right place.

\subsection{The chemical search for targets}

\subsubsection{Interaction of the ferrocifens with DNA.}

DNA has long been considered as the principal target for metallodrugs, in particular cisplatin. This is not the case with the ferrocifens. It has been shown that they do not react with purine bases ${ }^{61}$ and that DNA lesions appear clearly only at an elevated concentration of ferrocifens $(10 \mu \mathrm{M})$ and do not require the presence of phenol. ${ }^{29}$ There are two literature examples that describe interactions of the ferrocifens with DNA. In the first case, studied by 
Osella, one sees a degradation of the DNA based on the Comet assay on mesothelium cells (BBR cells from cancer of the pleura) after $2 \mathrm{~h}$ incubation in the presence of Fc-diOH (0.5 $\mu \mathrm{M}$ ) that is not seen in the presence of Fc-OH-Tam. ${ }^{75}$ The other example involves the effect of Fc-diPh on leukemia HL 60 cells. This complex induces apoptosis with an accumulation of cells in the G0/G1 phase and is followed by fragmentation of DNA, a result based on phosphatidylserine externalisation and increase of caspases 3 et $7 .^{58}$

\subsubsection{Interaction with thiols and thioredoxin reductases (TrxRs)}

Quinone methides are known to undergo nucleophilic additions, for example by thiols. In the case of quinone methides derived from ferrocifens obtained by chemical oxidation using $\mathrm{Ag}_{2} \mathrm{O}$, it has been found that they can participate in 1,8 Michael additions with certain thiols such as methyl $\mathrm{N}$-acetyl cysteine or glutathione; this is the preferred reaction in basic media. An in vitro study of the interaction of the ferrocifens with purified thioredoxin reductases ( $\operatorname{TrRx})$ confirmed that quinone methides interact with TrxRs when these active sites contain accessible selenols, but do not react with the corresponding thiols. ${ }^{76}$ This is a notable difference between the ferrocifens and OH-Tam. Indeed, the quinone methide of the latter is more reactive than those of the ferrocifens with the nucleophiles present in cells. It is also noteworthy that there is a difference in chemical reactivity between the quinone methides of Fc-OH-Tam and Fc-monoOH. The QM derived from Fc-monoOH can cyclise in a protic medium to form an indene, and this molecule can no longer undergo Michael additions. The effect of Fc-OH-Tam and Fc-monoOH on Jurkat cells shows that the strongest inhibition of the thioredoxin reductase is induced after incubation in the presence of Fc-OH-Tam. This indicates two things (1) that Fc-OH-Tam behaves like a pro-drug that is transformed in the cell into its quinone methide and (2) the very strong activity of Fc-OH-Tam is due to the fact that it remains in the cell in the state of a QM whereas the quinone methide of Fc-monoOH is partly transformed into an inactive indene (Scheme 6)

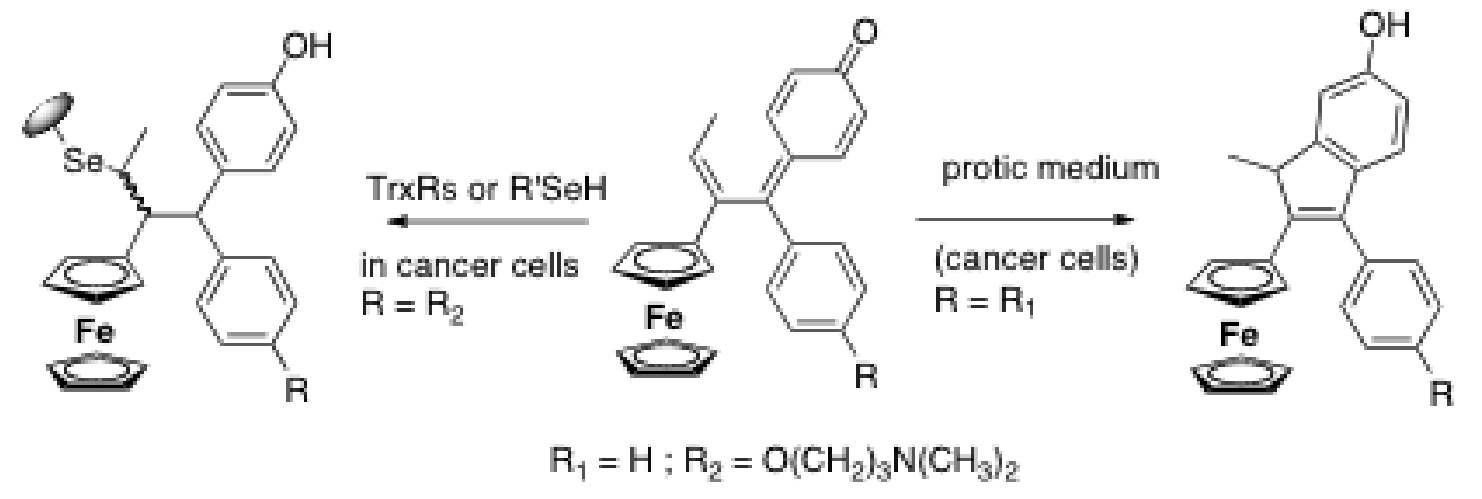


Scheme 6 : Reaction of quinone methides with selenols and competitive cyclisation to indene in protic medium. ${ }^{76}$

\subsection{In vivo studies with Fc-diOH, Fc-OH-Tam and ansa-Fc-diOH}

In vivo studies have been performed with the 3 hits: Fc-diOH, Fc-OH-Tam and ansaFc-diOH. There were several challenges to succeed in the transfer from in vitro to in vivo experiments. The first one was to find a formulation suitable for lipophilic molecules and the second one was to allow phenols to remain in the blood to reach their target (cancer cells) while it is well known that phenols are rapidly metabolized in the liver. The first experiments performed with oral administration of Fc-OH-Tam under its citrate salt and of Fc-diOH protected with palmitate functions on xenografted prostate tumors on nude mice did not induce regression of the tumors. ${ }^{77}$ This problem was solved with the development of nanotechnologies and more precisely with that of LNCs (lipid nanocapsules). These LNCs consist of a lipidic heart, in which ferrocifens are soluble, surrounded by modified PEG possessing a lipophilic head and a hydrophilic tail. All these constituents are FDA approved which is a significant advantage for their development. In addition their stealthiness increases their time of circulation in the body. This effect can be increased by addition of a second layer of PEG (mspPEG-2000). The effect of these LNCs loaded with Fc-diOH was first tested on rat with implanted tumors from glioblastoma (rat 9L cells) by direct injection in the tumor or intravenously. Significant to almost total regression of the tumors was observed with the second generation of LNCs. An increase in the number of injections does not seem to improve the effect of the drug (LNCs loaded with ansa-Fc-diOH). ${ }^{67}$ Very interesting results have been obtained on orthotopic tumors (9L cells implanted in rat brain) when chemotherapy, LNCs loaded with Fc-diOH and injected in rat brain, was coupled with radiotherapy. However it should be kept in mind that some LNCs exhibit a strong toxicity if administered directly in the brain while they are very efficient if delivered via an injection in the carotid. ${ }^{78}$ It remains that this formulation is particularly well suited for ferrocifens delivery.

\subsection{Hybrid Ferrocifen-SAHA and related species}

The idea of this study was to combine two active entities in the same molecule in order to modulate simultaneously several mechanisms of action. The choice was made to focus on the coupling of ferrocifens with SAHA (suberoylanilide hydroxamic acid). SAHA is an inhibitor of histone deacetylases (HDAC) which belong to an important class of epigenetic drugs. The hybrid compounds were obtained by replacing the amine chain of Fc-OH-Tam by 
a SAHA fragment. Thus, Fc-Tam-SAHA and Fc-Tam-PSA (the corresponding amide, PSA = $\mathrm{N}^{1}$-phenylsuberamide) were prepared as well as their organic analogues (Tam-SAHA and Tam-PSA; Scheme 7). ${ }^{47}$ The antiproliferative effect of these molecules was studied on breast cancer cells MDA-MB-231 cells (Table 4).

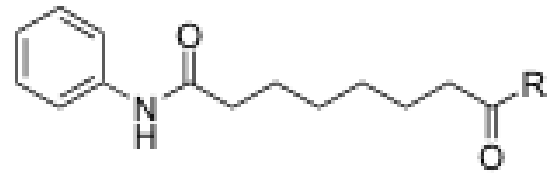

SAHA : $\mathrm{R}=\mathrm{NHOH}$

PSA : $\mathrm{R}=\mathrm{NH}_{2}$

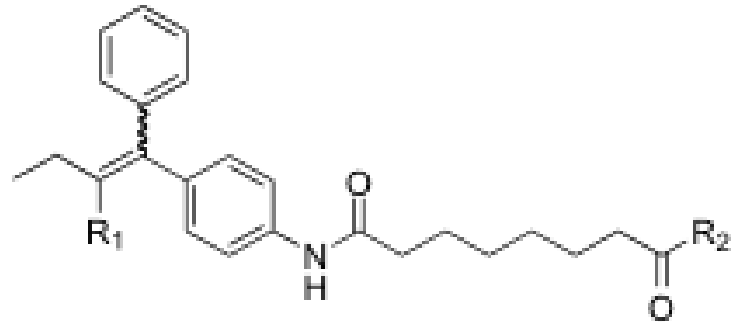

Fc-Tam-SAHA : $\mathrm{R}_{1}=\mathrm{FC} ; \mathrm{R}_{2}=\mathrm{NHOH}$

Tam-SAHA : $\mathrm{R}_{1}=\mathrm{Ph} ; \mathrm{R}_{2}=\mathrm{NHOH}$

Fc-Tam-PSA : $\mathrm{R}_{1}=\mathrm{FC}_{\mathrm{C}} ; \mathrm{R}_{2}=\mathrm{NH}_{2}$

Tam-PSA : $\mathrm{R}_{1}=\mathrm{OH} ; \mathrm{R}_{2}=\mathrm{NH}_{2}$

Scheme 7 : Structure of SAHA, PSA and of their ferrocifen and tamoxifen hybrids

Table 4 : IC $_{50}$ values $(\mu \mathrm{M})$ of organic and ferrocenyl hybrids of SAHA and PSA on MDAMB-231 cancer cells after $72 \mathrm{~h} .{ }^{47}$

\begin{tabular}{|l|c|c|c|c|c|l|}
\hline Compound & SAHA & Fc-Tam & $\begin{array}{l}\text { FC-Tam- } \\
\text { SAHA }\end{array}$ & Tam-SAHA & $\begin{array}{l}\text { Fc-Tam- } \\
\text { PSA }\end{array}$ & $\begin{array}{l}\text { Tam- } \\
\text { PSA }\end{array}$ \\
\hline $\mathbf{I C}_{\mathbf{5 0}}(\boldsymbol{\mu M})$ & $3.6 \pm 0.5$ & $2.6 \pm 0.7$ & $0.7 \pm 0.1$ & $8.6 \pm 0.8$ & $0.5 \pm 0.1$ & $25.2 \pm 4.9$ \\
\hline
\end{tabular}

Interestingly, a synergic effect between SAHA and Fc-Tam was observed for Fc-TamSAHA ( IC $_{50}$ value of $0.7 \mu \mathrm{M}$ versus $3.6 \mu \mathrm{M}$ for SAHA and $2.6 \mu \mathrm{M}$ for Fc-Tam). This synergic effect was not observed for organic molecules Tam-SAHA or Tam-PSA $\left(\right.$ IC $_{50}=8.6$ and $25.2 \mu \mathrm{M}$ respectively). However, both Fc-Tam-SAHA and Tam-SAHA have been found to exhibit an HDAC inhibition effect with similar activity. This effect is weaker than that observed for SAHA. This result seems to prove that antiproliferative effect of Fc-Tam-SAHA is not mainly related to its HDAC inhibition effect. Moreover, the antiproliferative effect of compounds against hormone-dependent breast cancer cells does not correlate with the interaction of compounds with estradiol receptors even though they were recognized by estradiol receptors with RBA values in the range 4-22\%. Interestingly, it was found that FcTam-SAHA and Fc-Tam-PSA significantly increase the p21mRNA expression in MCF-7 cells. This expression may account for the antiproliferative effect of these compounds as ferrocifens were found to produce ROS. However, the antiproliferative behaviour of Fc-TamPSA is still not fully understood. 


\subsection{Complexes with two amino chains}

Another family of complexes is made up of species possessing two amino chains (Chart 4, Series G). These are secondary products obtained in the McMurry synthesis, and different complexes have been prepared. ${ }^{79,80}$ It has been found that although these complexes do not possess a phenolic group they have an affinity for the estradiol receptor which expresses itself, at low concentration $(0.1 \mu \mathrm{M})$, by a proliferative effect on MCF-7 cells and then a toxic effect leading to $\mathrm{IC}_{50}$ values around $0.5 \mu \mathrm{M}$. Interestingly, this time the antiproliferative effect is not associated with the presence of a metallocene but is uniquely attributable to the presence of the double amino chains. Furthermore, these complexes exhibit strong antibacterial effects. One hypothesis of the mechanism of action involves complexation of a zinc atom. We note that these are the only complexes that possess a strong antibacterial effect; ${ }^{23}$ likewise, other symmetric amines, such as ridaifin $\mathrm{B}$, have also been found to exhibit a strong antibacterial effect. ${ }^{80}$

\section{Conclusion}

Organometallic chemistry, which has been one of the major strengths of molecular chemistry over the past sixty years, particularly in terms of homogenous catalysis, is now seeing the supremacy of this established topic challenged by emerging fields such as organometallic medicinal chemistry where derivatives of metallocenes, such as ferrocene, provide archetypal examples. $^{81}$

In this article we have attempted to bring together mechanistic data, both chemical and biological, relating to the ferrocifens. This series was conceived initially as ferrocenyl derivatives of tamoxifen - the primary prodrug to combat hormone-dependent breast cancers — in an attempt to extend the range of applicability to hormone-independent cancers. However, these complexes soon broke free from this important but limited tether when their activity against other currently incurable types of cancer became apparent; we have now reached the point at which we can begin to hope that they may be considered as possible complements to the coordination complexes of cisplatin and related systems. Furthermore, it quickly became apparent that the ferrocifens, unlike the platinum complexes, targeted primarily not the DNA bases but rather the proteins.

Among the library of ferrocenyl compounds that have been synthesised, attention has focussed on the following three hits: Fc-OH-Tam (the first example prepared in the acyclic series), its corresponding diphenol Fc-diOH, and its cyclic analogue ansa-Fc-diOH. Our understanding of the behaviour of these three hits has benefitted both the chemical and 
biological studies, as shown in the sections above. This has allowed us to analyse their similarities and differences and to achieve a deeper understanding on a number of fronts.

The study of the metabolites obtained by oxidation, either chemically with $\operatorname{Ag}_{2} \mathrm{O}$, or biologically with cytochrome P450 (from liver microsomes or purified) have revealed the importance in the open series (Fc-OH-Tam, Fc-diOH et Fc-monoOH) of a quinone methide metabolite subject to evolution. These QMs are electrophiles which are selective for thiolates and selenols, which is not the case for their more reactive organic analogues. This provides an explanation for the selective inhibitory activity of the organometallics on thioredoxin reductase, an enzyme overexpressed in cancerous cells. Nevertheless, during the incubation of these complexes with Jurkat cells, the effect of Fc-monoOH seems to be diminished because of cyclisation of the quinone methide. Moreover, these ferrocifenyl entities, which are frequently producers of ROS, are active essentially on cancerous cells and are much less so on healthy cells. The ferrocifens take advantage of the micro-environment of the cancerous cell and make possible this selectivity associated with a general lowering of toxicity.

Chemically, the case of ansa-Fc-diOH is different since the QM species expected to be formed upon oxidation has never been detected. This does not prevent the complex from having one of the strongest antiproliferative effects found in this family of molecules. Although it was not possible to detect the signature of this QM electrochemically, initial oxidation of the iron is evident. One can explain this behaviour in terms of the high level of strain imposed by the three-carbon bridge which prevents the two cyclopentadienyl rings from becoming fully parallel and does not allow the planarity required for the QM. The active species could therefore be the radical precursor of the QM. This may be a more widespread type of behaviour.

Although ansa-Fc-diOH and Fc-diOH have shown differences in their oxidative progress concerning the formation, or not, of a quinone methide, their biological behaviour provides some analogies. For example, selectivity for the same cell lines (kidney, leukemia, central nervous system) in the NCI panel of 60 cell lines. Moreover, as for Fc-OH-Tam, the two species induce senescence at low concentration $(0.1 \mu \mathrm{M})$ and, depending on the cancer cell, a possibility of apoptosis at higher concentrations $(>1 \mu \mathrm{M})$ as a function of the sensitivity of the cell to pro-apoptotic stimuli. The discovery of this senescence is not without therapeutic interest since it could provide a promising alternative to cytotoxic compounds, in particular to avoid the problem of their chemoresistance. Senescence involves an irreversible cessation of proliferation. This effect has also been established in a number of benign 
adenomas. $^{82}$ One can envisage taking advantage of senescence for the stabilisation of patients in advanced stages of cancer who no longer respond to cytotoxic agents on cells resistant to apoptosis but respond to senescence, also in the treatment of precancerous or early stage tumours, and as a potential strategy to combat resistance.

It must be stressed that, when working with these often lipophilic organometallic entities, the formulation is key to the efficacy of the system. In this context, stealth lipid nanocapsules (LNCs) have proved to be useful when their composition can be adapted to their mode of administration and to the type of tumour studied (ectopic or orthotopic).

The ferrocifens mentioned above have shown their ability to interact according to both their structure and the nature of the cancer cell targets (whether or not these respond to proapoptopic stimuli), as well as their formulation; in addition, this ability to interact also depends on their biological concentration which allows the activation of any given target, dependent of course on their presence inside the particular cell. The scheme below (Chart 7) summarises the effects of concentration:

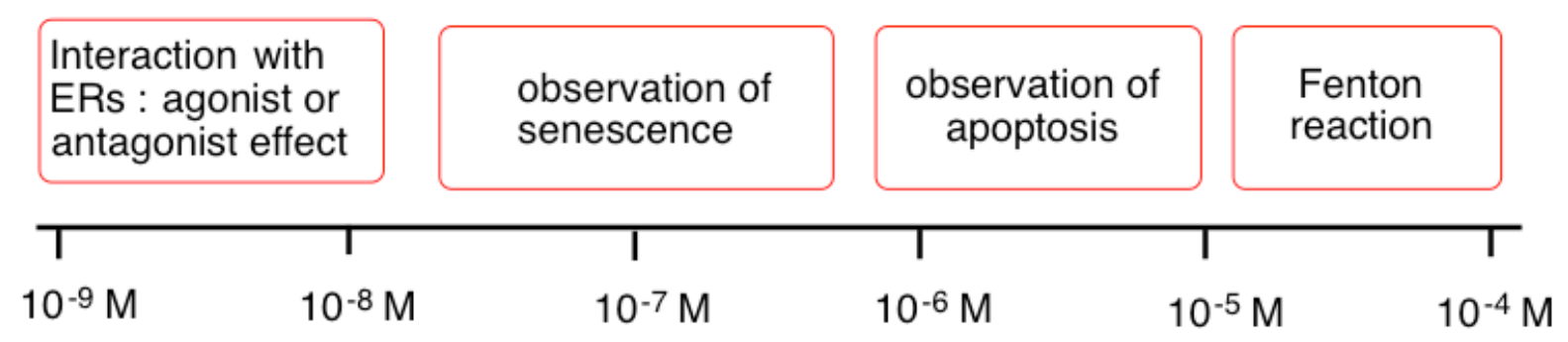

Chart 7 : In vitro effects of ferrocifens on cancer cells vary according to their concentration in the biological medium

The concentration regions where one or another biological signalling pathway predominates are quite well defined, but their capacity for action, synergic or otherwise, requires further elucidation and other pathways must still be identified. The possibility of activity at concentrations appropriate for Fenton reactions, which engender a genotoxic effect by producing hydroxyl radicals, is encouraging for the potential utility of our molecules. In addition, multitargetting of the ferrocifens provides a broad spectrum of efficacy and the potential to significantly delay or even suppress drug resistance.

It is clear that other targets still remain to be found, as illustrated by the ferrocifenSAHA hybrids that possess a strong antiproliferative effect even though they cannot lead to active QM species. Their activity could be associated with initiation of the expression of the p21 gene recognised as a powerful inducer of senescence also observed with Fc-diOH and ansa-Fc-diOH. 
Although the systems above do not possess the Fc-alkene-paraphenol motif, it is still true that research on molecules containing this structural element remains a useful approach in the quest for new prodrugs ; for example, the case of Feroscan 53 shown below :

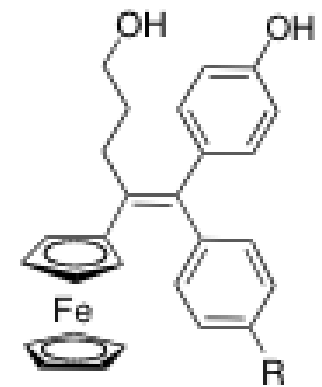

Ferroscan 53 (FSC 53)

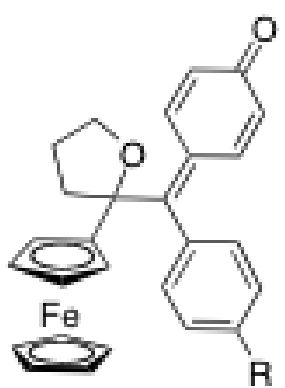

QM FSC 53

Scheme 8 : Ferrocifens with modified alkyl chain

This product with $\mathrm{R}=\mathrm{OH}$ is very active on MDA-MB-231 $\left(\mathrm{IC}_{50}=0.1 \mu \mathrm{M}\right)$ or HepG2 $\left(\mathrm{IC}_{50}=\right.$ $0.07 \mu \mathrm{M})$ cells. $^{83}$ Oxidation leads to a novel type of heterocyclic quinone and opens new pathways to explore in the area of biodiversity.

One can now see the richness of this family of the ferrocifens and the promise of applications that must be studied in more depth. This exploration will still take time to develop, but in light of the results already obtained there is reason of optimism. One can hope that this review may stimulate other, more biochemically focused groups, to extend these studies to include metabolomic or microarray expression profiling of appropriate cell lines to deconvolute the multiple pathways involved.

\section{$5 \quad$ Acknowledgements}

We wish to thank our co-workers named in the cited papers and Dr Patricia de Cremoux. Barbara McGlinchey and Michael McGlinchey are acknowledged for fruitful discussions and their linguistic talents; the LabEx Michem for scientific support. We also thank the Pierre-Gilles De Gennes Foundation, the University PSL, Feroscan and IRCP for generous support. 


\section{References}

1. L. M. Jarvis, Chemical \& Engineering News, 2015, 93, 11.

2. M. R. Alison, The Cancer Handbook, 2nd Edition, Wiley and Sons, 2007.

3. M. Bower and J. Waxman, Lecture Notes: Oncology, 3rd Edition, Wiley-VCH Verlag, 2015.

4. N. P. E. Barry and P. J. Sadler, Chem. Commun. , 2013, 49, 5106-5131.

5. J. Reedijk, Eur. J. Inorg. Chem., 2009, 1303-1312.

6. A. A. Nazarov, C. G. Hartinger and P. J. Dyson, J. Organomet. Chem., 2014, 751, 251-260.

7. J. M. Hearn, I. Romero-Canelon, A. F. Miunro, Y. Fu, A. M. Pizarro, M. J. Garnett, U. McDermott, N. Carragher and P. J. Sadler, Proc. Natl. Acad. Sci. U S A, 2015, 112, E3800E3805.

8. G. Jaouen, W. Beck and M. J. McGlinchey, in Bioorganometallics ed. G. Jaouen, Wiley-VCH, Weinheim, 2006, Chap 1, pp. 1-37.

9. G. Jaouen and A. Vessières, Pure Appl. Chem., 1985, 57, 1865-1874.

10. C. G. Hartinger and P. J. Dyson, Chem. Soc. Rev., 2009, 38, 391-401.

11. R. Alberto, in Bioinorganic Medicinal Chemistry, ed. E. Alessio, Wiley-VCH, 2011, p. 253.

12. P. Anstaett and G. Gasser, in Bioorganometallic Chemistry, eds. G. Jaouen and M. Salmain, Wiley-VCH, 2015, p. 3.

13. M. A. Cinellu, I. Ott and A. Casini, in Bioorganometallic Chemistry, eds. G. Jaouen and M. Salmain, Wiley-VCH, 2015, p. 117.

14. A. Deally, F. Hackenberg, G. Lally, H. Mueller-Bunz and M. Tacke, Organometallics, 2012, 31, 5782-5790.

15. N. J. Farrer and P. J. Sadler, in Bioinorganic Medicinal Chemistry, ed. E. Alessio, Wiley-VCH, 2011, p. 1.

16. G. Gasser, I. Ott and N. Metzler-Nolte, J. Med. Chem., 2011, 54, 3-25.

17. M. Hanif, M. V. Babak and C. G. Hartinger, Drug Discov.Today, 2014, 19, 1640-1648.

18. C. G. Hartinger, N. Metzler-Nolte and P. J. Dyson, Organometallics, 2012, 31, 5677-5685.

19. L. Oehninger, R. Rubbiani and I. Ott, Dalton Trans., 2013, 42, 3269-3284.

20. B. Cetinkaya, E. Cetinkaya, H. Kucukbay and R. Durmaz, Arzneim. Forsch., 1996, 46, 821-823.

21. J. J. Soldevila-Barreda, I. Romero-Canelon, A. Habtemariam and P. J. Sadler, Nature Commun., 2015, 6, 6582.

22. F. Dubar and C. Biot, in Bioorganometallic Chemistry eds. G. Jaouen and M. Salmain, WileyVCH, Weinheim, 2015, Chap.5, pp. 141-164.

23. M. El Arbi, P. Pigeon, S. Top, A. Rhouma, S. Aifa, A. Rebai, A. Vessieres, M. A. Plamont and G. Jaouen, J. Organomet. Chem., 2011, 696, 1038-1048.

24. M. Patra, G. Gasser and N. Metzler-Nolte, Dalton Trans., 2012, 41, 6350-6358.

25. S. S. Braga and A. M. S. Silva, Organometallics, 2013, 32, 5626-5639.

26. E. A. Hillard, A. Vessières and G. Jaouen, in Medicinal Organometallic Chemistry, eds. G. Jaouen and N. Metzler-Nolte, Springer, Heidelberg, 2010, pp. 81-117.

27. G. Jaouen and S. Top, in Advances in Organometallic Chemistry and Catalysis, ed. A. Pombeiro, Wiley, 2014, Chap. 42, pp. 561-580.

28. S. Top, J. Tang, A. Vessières, D. Carrez, C. Provot and G. Jaouen, Chem. Commun., 1996, 955956.

29. S. Top, A. Vessières, C. Cabestaing, I. Laios, G. Leclercq, C. Provot and G. Jaouen, J. Organomet. Chem., 2001, 637, 500-506.

30. S. Top, A. Vessières, G. Leclercq, J. Quivy, J. Tang, J. Vaissermann, M. Huché and G. Jaouen, Chem. Eur. J., 2003, 9, 5223-5236.

31. Y. F. Zheng, C. H. Wang, C. H. Li, J. X. Qiao, F. Zhang, M. J. Huang, W. M. Ren, C. N. Dong, J. Huang and H. B. Zhou, Org. \& Biomol. Chem., 2012, 10, 9689-9699. 
32. A. P. Ferreira, J. L. Ferreira da Silva, M. T. Duarte, M. F. Minas da Piedade, M. P. Robalo, S. G. Harjivan, C. Marzano, V. Gandin and M. M. Marques, Organometallics, 2009, 28, 5412-5423.

33. D. Plazuk, A. Vessières, E. A. Hillard, O. Buriez, E. Labbé, P. Pigeon, M. A. Plamont, C. Amatore, J. Zakrzewski and G. Jaouen, J. Med. Chem., 2009, 52, 4964-4967.

34. O. Payen, S. Top, A. Vessières, E. Brulé, M.-A. Plamont, M. J. McGlinchey, H. Müller-Bunz and G. Jaouen, J. Med. Chem., 2008, 51, 1791-1799.

35. D. Plazuk, A. Wieczorek, A. Blauz and B. Rychlik, MedChemComm., 2012, 3, 498-501.

36. J. P. Monserrat, K. N. Tiwari, L. Quentin, P. Pigeon, G. Jaouen, A. Vessières, G. G. Chabot and E. A. Hillard, J. Organomet. Chem., 2013, 734, 78-85.

37. K. Kowalski, L. Szczupak, L. Oehninger, I. Ott, P. Hikisz, A. Koceva-Chyla and B. Therrien, J. Organomet. Chem., 2014, 772, 49-59.

38. A. Arezki, G. G. Chabot, L. Quentin, D. Scherman, G. Jaouen and E. Brulé, MedChemComm., 2011, 2, 190-195.

39. S. Knauer, B. Biersack, M. Zoldakova, K. Effenberger, W. Milius and R. Schobert, Anti-Cancer Drugs, 2009, 20, 676-681.

40. J. Amin, I. S. Chuckowree, M. Wang, G. J. Tizzard, S. J. Coles and J. Spencer, Organometallics, 2013, 32, 5818-5825.

41. C. W. Ong, J. Y. Jeng, S. S. Juang and C. F. Chen, Bioorg. Med. Chem. Lett. , 1992, 2, 929-932.

42. A. A. Simenel, E. A. Morozova, L. V. Snegur, S. I. Zykova, V. V. Kachala, L. A. Ostrovskaya, N. V. Bluchterova and M. M. Fomina, Appl. Organomet. Chem. , 2009, 23, 219-224.

43. P. James, J. Neudoerfl, M. Eissmann, P. Jesse, A. Prokop and H.-G. Schmalz, Org. Lett., 2006, 8, 2763-2766.

44. H. V. Nguyen, A. Sallustrau, J. Balzarini, M. R. Bedford, J. C. Eden, N. Georgousi, N. J. Hodges, J. Kedge, Y. Mehellou, C. Tselepis and J. H. R. Tucker, J. Med. Chem., 2014, 57, 5817-5822.

45. A. D. S. Krishna, G. Panda and A. K. Kondapi, Arch. Biochem. Biophys. , 2005, 438, 206-216.

46. B. Balaji, B. Balakrishnan, S. Perumalla, A. A. Karande and A. R. Chakravarty, Eur. J. Inorg. Chem. , 2015, 1398-1407.

47. J. d. J. Cazares Marinero, M. Lapierre, V. Cavailles, R. Saint-Fort, A. Vessieres, S. Top and G. Jaouen, Dalton Trans., 2013, 42, 15489-15501.

48. A. Mooney, R. Tiedt, T. Maghoub, N. O'Donovan, J. Crown, B. White and P. T. M. Kenny, J. Med. Chem., 2012, 55, 5455-5466.

49. S. B. Deepthi, R. Trivedi, L. Giribabu, P. Sujitha and C. G. Kumar, Dalton Trans., 2013, 42, 1180-1190.

50. S. Daum, V. F. Chekhun, I. N. Todor, N. Y. Lukianova, Y. V. Shvets, L. Sellner, K. Putzker, J. Lewis, T. Zenz, I. A. M. de Graaf, G. M. M. Groothuis, A. Casini, O. Zozulia, F. Hampel and A. Mokhir, J. Med. Chem., 2015, 58, 2015-2024.

51. J. E. McMurry, Acc. Chem. Res., 1983, 16, 405.

52. G. Jaouen, S. Top, A. Vessières, G. Leclercq, J. Quivy, L. Jin and A. Croisy, C. R. Acad. Sci. Paris, Série Ilc,2000, 3, 89-93.

53. L.-A. Haldosen, C. Zhao and K. Dahlman-Wright, Mol. Cell. Endocrinol., 2014, 382, 665-672.

54. A. K. Shiau, D. Barstad, P. M. Loria, L. Cheng, P. J. Kushner, D. A. Agard and G. L. Greene, Cell, 1998, 95, 927-937.

55. S. Top, C. Thibaudeau, A. Vessières, E. Brulé, F. Le Bideau, J. M. Joerger, M. A. Plamont, S. Samreth, A. Edgar, J. Marrot, P. Herson and G. Jaouen, Organometallics 2009, 28, 1414-1424.

56. Q. Michard, G. Jaouen, A. Vessières and B. A. Bernard, J. Inorg. Biochem., 2008, 102, 19801985.

57. E. Allard, C. Passirani, E. Garcion, P. Pigeon, A. Vessières, G. Jaouen and J. P. Benoit, J. Control. Release, 2008, 130, 146-153.

58. A. C. de Oliveira, E. G. da Silva, D. D. Rocha, E. A. Hillard, P. Pigeon, G. Jaouen, F. A. R. Rodrigues, F. C. de Abreu, F. d. R. Ferreira, M. O. F. Goulart and L. V. Costa-Lotufo, ChemMedChem, 2014, 9, 2580-2586. 
59. A. Nguyen, A. Vessières, E. A. Hillard, S. Top, P. Pigeon and G. Jaouen, Chimia, 2007, 61, 716724.

60. P. Pigeon, S. Top, O. Zekri, E. A. Hillard, A. Vessières, M. A. Plamont, O. Buriez, E. Labbé, M. Huché, S. Boutamine, C. Amatore and G. Jaouen, J. Organomet. Chem., 2009, 694, 895-901.

61. M. Görmen, P. Pigeon, S. Top, E. A. Hillard, M. Huché, C. G. Hartinger, F. de Montigny, M.-A. Plamont, A. Vessières and G. Jaouen, ChemMedChem, 2010, 5, 2039-2050.

62. A. C. de Oliveira, E. A. Hillard, P. Pigeon, D. D. Rocha, F. A. R. Rodrigues, R. C. Montenegro, L. V. Costa-Lotufo, M. O. F. Goulart and G. Jaouen, Eur. J. Med. Chem., 2011, 46, 3778-3787.

63. C. Bruyère, V. Mathieu, A. Vessières, P. Pigeon, S. Top, G. Jaouen and R. Kiss, J. Inorg. Biochem., 2014, 141, 144-151.

64. A. Vessières, C. Corbet, J. M. Heldt, N. Lories, N. Jouy, I. Laios, G. Leclercq, G. Jaouen and R. A. Toillon, J. Inorg. Biochem., 2010, 104, 503-511.

65. C. Lu, J.-M. Heldt, M. Guille-Collignon, F. Lemaitre, G. Jaouen, A. Vessieres and C. Amatore, ChemMedChem, 2014, 9, 1286-1293.

66. H. Z. S. Lee, O. Buriez, F. Chau, E. Labbé, R. Ganguly, C. Amatore, G. Jaouen, A. Vessières, W. K. Leong, S. Top, Eur. J. Inorg. Chem. 2015, 4217-4226

67. A.-L. Lainé, A. Clavreul, A. Rousseau, C. Tétaud, A. Vessières, E. Garcion, G. Jaouen, L. Aubert, M. Guilbert, J. P. Benoit, R. A. Toillon and C. Passirani, Nanomedicine: NBM, 2014, 10, 16671677.

68. E. A. Hillard, A. Vessières, L. Thouin, G. Jaouen and C. Amatore, Angew. Chem. Int. Ed., 2006, 45, 285-290.

69. P. Köpf-Maier, H. Köpf and E. W. Neuse, Angew. Chem. Int. Ed. Engl., 1984, 23, 456-457.

70. D. Osella, M. Ferrali, P. Zanello, F. Laschi, M. Fontani, C. Nervi and G. Cavigiolio, Inorg. Chim. Acta, 2000, 306, 42-48.

71. A. Nguyen, V. Marsaud, C. Bouclier, S. Top, A. Vessières, P. Pigeon, R. Gref, P. Legrand, G. Jaouen and J.-M. Renoir, Int. J. Pharmaceut. , 2008, 347, 128-135.

72. P. Messina, E. Labbé, O. Buriez, E. A. Hillard, A. Vessières, D. Hamels, S. Top, G. Jaouen, Y. M. Frapart, D. Mansuy and C. Amatore, Chem. Eur. J., 2012, 18, 6581-6587.

73. D. Hamels, P. M. Dansette, E. A. Hillard, S. Top, A. Vessières, P. Herson, G. Jaouen and D. Mansuy, Angew. Chem. Int. Ed, 2009, 48, 9124-9126.

74. M.-A. Richard, D. Hamels, P. Pigeon, S. Top, P. M. Dansette, H. Z. S. Lee, A. Vessières, D. Mansuy and G. Jaouen, ChemMedChem 2015, 10, 981-990.

75. I. Zanellato, J. M. Heldt, A. Vessières, G. Jaouen and D. Osella, Inorg. Chim. Acta, 2009, 362, 4037-4042.

76. A. Citta, A. Folda, A. Bindoli, P. Pascal Pigeon, S. Top, A. Vessières, M. Salmain, G. Jaouen and M. P. Rigobello, J. Med. Chem., 2014, 57, 8849-8859.

77. A. Vessières, J. Organomet. Chem., 2013, 734, 3-16.

78. A. L. Laine, N. T. Huynh, A. Clavreul, J. Balzeau, J. Bejaud, A. Vessieres, J. P. Benoit, J. Eyer and C. Passirani, Eur. J. Pharmaceut. Biopharmaceut., 2012, 81, 690-693.

79. K. Nikitin, Y. Ortin, H. Muller-Bunz, M. A. Plamont, G. Jaouen, A. Vessières and M. J. McGlinchey, J. Organomet. Chem., 2010, 695, 595-608.

80. P. Pigeon, S. Top, A. Vessières, M. Huché, M. Gormen, M. El Arbi, M. A. Plamont, M. J. McGlinchey and G. Jaouen, New J. Chem., 2011, 35, 2212-2218.

81. J. Held, C. Supan, C. L. O. Salazar, H. Tinto et al. Lancet Infect. Dis., 2015, doi: 10.1016/S14733099(15)00079-1.

82. J. A. Ewald, J. A. Desotelle, G. Wilding and D. F. Jarrard, JNCI-J. Natl. Cancer Inst., 2010, 102, 1536-1546.

83. Y. Wang, P. Pigeon, S. Top, M. J. McGlinchey, G. Jaouen, Angew. Chem. Int. Ed. 2015, 54, 10230-10233 


\section{Table of Content}

The mechanisms of action of ferrocifens depend on several features : chemical structures, used concentrations, nature of cancer cells
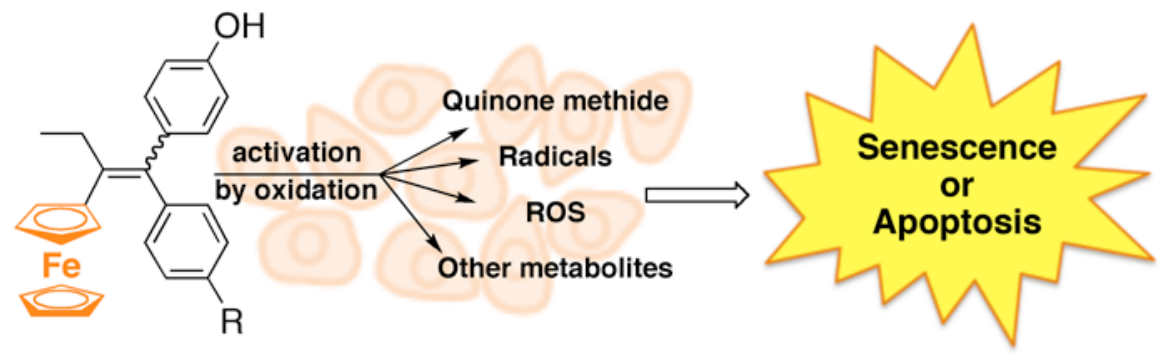